\title{
Genomic Analysis Reveals Strong Signatures of Selection in Guangxi Three-Yellow Chicken in China
}

\author{
Yuying Liao ${ }^{1}$, Junli Sun ${ }^{1}$, Yingfei Huang ${ }^{1}$, Fengying $\mathrm{Wei}^{1}$, Guodong $\mathrm{Mo}^{1}$, Lucas Zellmer $^{3}$, and Dezhong Joshua Liao ${ }^{2}$. \\ ${ }^{1}$ Guangxi Academy of Agricultural Sciences, Guangxi Key Laboratory on Livestock Genetic and Improvement, Nanning, Guangxi 530001, P.R. China \\ ${ }^{2}$ Laboratory of Core Facilities, The Second Hospital, Guizhou University of Traditional Chinese Medicine, 32 Feishan Street, Guiyang 550001, Guizhou Province, China \\ ${ }^{3}$ Masonic Cancer Center, University of Minnesota, 435 E. River Road, Minneapolis, MN 55455, USA \\ *Corresponding author`s Email: 315951610@qq.com; djliao@gzy.edu.cn; ORCID: 0000-0003-3904-349X
}

Received: 29 Jun. 2020

Accepted: 20 Aug. 2020

\begin{abstract}
Much like other indigenous domesticated animals, Guangxi Three-yellow chickens (GX-TYC) in China have experienced strong selective pressure, and show specific phenotypic changes in physiology, morphology and behavior. To identify genomic footprints or selection signatures left by artificial selection during domestication of GX-TYC, the whole genomes of 12 GX-TYC hens were sequenced to executed selective sweep analyses and gene functional enrichment analysis (Gene Ontology and Kyoto Encyclopedia of Genes and Genome pathways). A total of 10.13 million single nucleotide polymorphisms and 842,236 insertion/deletion polymorphisms (Indels) were found. Forty-six windows showed a Z score of heterozygosity (ZHp) lower than -5 , which potentially were considered to be positively selected regions. Gene annotation identified 55 genes in these regions. Selection signatures were found mainly on the SSC5, SSC8, SSC23 and SSCZ. GO and KEGG analyses revealed that these genes were related to growth, immune responses as well as carbohydrate, lipid and amino acid metabolisms. In addition, two genes, fructose-1,6-bisphosphatase 1 and fructose-1,6-bisphosphatase 2 were enriched into four signaling pathways, three of which are involved in carbohydrate metabolism and insulin signaling. SHC3, FANCC and PTCH1, in combination with FB1 and FBP2, were clustered together in a region of chromosome Z, and thus might have been selected together. The results have uncovered some genetic footprints of chicken domestication, providing not only an important resource for further improvements of fowl breeding, but also a useful framework for future studies on the genetics of domestic chickens as well as on the phenotypic variations and certain diseases of chickens.
\end{abstract}

Key words: Chicken; Selective sweeps; Single nucleotide polymorphism; Whole genome resequencing

\section{INTRODUCTION}

Three-yellow chicken (TYC) is internationally well known for its desirable meat quality including juiciness, flavor and tenderness. They were named for their yellow feather, yellow beak and yellow feet. Three-yellow chicken is not a particular species, but rather is a collective name for those chicken breeds with these three yellow traits, including Huxu, Qingyuan, Xinghua, Huaixiang, Wenchang and Yangshan chickens in the Guangdong province, Pudong chicken in Shanghai, Xiaoshan chicken in the Zhejiang province, etc. (Zheng et al.1989). Guangxi three-yellow chicken (GX-TYC), a breed that has been intensively selected both naturally and artificially, is mainly distributed in Yulin, Beiliu, Bobai, Cenxi counties or cities in the Guangxi province as a typical traditional breed locally. Because of its aforementioned meat quality, GX-TYC has been widely used in the development of many special lines of yellow-feather broilers in China (Wei et al. 2019). For future breeding efforts to develop better breeds for the broiler industry, a better understanding of the GX-TYC domestication and identify genetic components obtained from various selections that are likely the consequence of GX-TYC domestication are needed. For these purposes, the whole genome sequencing approach to explore favorable alleles, candidate mutations or single nucleotide polymorphisms (SNPs), and insertions/deletions (Indel) of TX-TYC were used, and the resulting data were reported herein.

\section{MATERIALS AND METHODS}

\section{Ethical approval}

All animal procedures used in this study were carried out in accordance with the Guide for Care and Use of Laboratory Animals (8th edition, released by the National 
Research Council, USA) and were approved by the Institutional Animal Care and Use Committee (IACUC) of Guangxi Institute of Animal Science.

\section{Sequencing of the Guangxi Three-yellow chicken genome}

Twelve GX-TYC hens raised at Chunmao Farming Co. Ltd. of Guangxi, China, were used in this study. Blood samples were collected from the wing vein using standard venipuncture. Genomic DNA was isolated from the blood samples with a bloodGen Mini Kit (Cwbiotech., China), and it was assessed for purity and quality using NanoDrop and gel electrophoresis. A pair-end library with insert sizes varying from 250 to 300 base-pairs (bp) was constructed and sequenced with the Illumina Hiseq 2000/2500 platform by BerryGenomics Biotechnology Co., Ltd., Beijing, China. Raw reads contained some interference information, including the adapter, low quality paired reads and unidentified nucleotides. Clean reads were obtained by removing this interference information ( $\mathrm{Li}$ et al., 2010), and were mapped onto the chicken reference genome (Gallus gallus, Galgal 14.78) using the BWA software (Li and Durbin, 2009).

\section{Single nucleotide polymorphisms and insertion/deletion polymorphisms Calling}

After the alignment, SNP and InDel calling using a Bayesian approach implemented in the package SAMtools were performed. The 'mpileup' command was used to identify SNPs and InDels with the parameters as '- $\mathrm{m} 2$-F 0.002 -d 1000'. The identified SNPs were filtered with more stringent parameters, i.e., coverage depth $\geq 4$, and Root Mean Square (RMS) mapping quality $\geq 20$, to obtain high quality SNPs, which were annotated using the Ensembl gene sets (http://www.ensembl.org/biomart/). The SNPs and InDels in gene regions were annotated using the ANNOVAR annotation tool (Wang et al., 2010).

\section{Selective sweep analysis}

Selective sweep screen was performed with the sequenced DNA pools. Allele counts at each SNP position were used to detect signatures of selection in $200-\mathrm{Kb}$ sliding windows with a step size of $50 \%$ overlapping for the genome sequences of GX-TYC. At each detected SNP position, the sums of major and minor alleles $\left(\mathrm{n}_{\mathrm{MAJ}}\right.$ and $\mathrm{n}_{\text {MIN }}$ ) were determined, and then the corresponding heterozygosity score were calculated using the following formula: $\mathrm{Hp}=2 \sum \mathrm{n}_{\mathrm{MAJ}} \sum \mathrm{n}_{\mathrm{MIN}} /\left(\sum \mathrm{n}_{\mathrm{MAJ}}+\sum \mathrm{n}_{\mathrm{MIN}}\right)^{2}$. Individual $\mathrm{Hp}$ was then Z-transformed to a standard normal distribution as follows: $\mathrm{ZHp}=(\mathrm{Hp}-\mu \mathrm{Hp}) / \sigma \mathrm{Hp}$. A threshold of $\mathrm{ZHp} \leq-5$ was set for putative selective sweeps because windows below it ended the distribution (Rubin et al., 2012).

\section{Analysis of functional enrichment}

Functional enrichment analysis of Gene Ontology (GO), as well as Kyoto Encyclopedia of Genes and Genome (KEGG) pathways were performed using "Benjamini-corrected modified Fisher's exact test" in the DAVID web server (Huang et al., 2009). Genes were mapped onto their respective human orthologs. $P$ values that indicated the significance of the overlap between various gene sets were corrected with BenjaminiHochberg false discovery rate (FDR). Only were terms with a $P$ value less than 0.05 considered significant, and were listed. The GO categories "biological processes", "molecular function" and "cellular component" were used in these analyses.

\section{RESULTS AND DISCUSSION}

\section{Data production and short read alignment}

Sequencing of the GX-TYC genome generated a total of $35.85 \mathrm{Gbs}$ of paired-end DNA sequences, of which $35.58(99.25 \%)$ Gbs of high quality paired-end reads were mapped onto the chicken reference genome assembly (Gallus_gallus, Galgal 4.78) with 33.66-fold sequence depth using Burrows-Wheeler-Alignment tool (BWA). Several categories of genetic variation, including SNPs and Indels were identified between the uniquely mapped reads and the reference genome.

\section{Single nucleotide polymorphisms and insertion/deletion polymorphisms Identification \\ Mapping the sequencing reads to the reference} genome revealed about 0.13 million SNPs, which exceeded the findings reported in the literature (Wong et al., 2004; Fan et al., 2013). A total of 4,332,562 (43\%) SNPs located in genic regions, of which 125,732 were coding ones that leaded to 37,045 nonsynonymous nucleotide substitutions (291 stop gains, 47 stop losses and 36,707 being non-synonymous) detected in a total of 5,839 genes (Figure 1 and supplementary table 1). Identification of 842,236 small Indel polymorphisms ranging from 1 to 50 bps in length (Supplementary table 2) was done, which tended to be detected with a greater frequency than their longer counterparts. About $43 \%$ of the Indels were in genic regions, similar to the distribution of SNPs, of which 1613 located in coding sequences (Figure 1). 


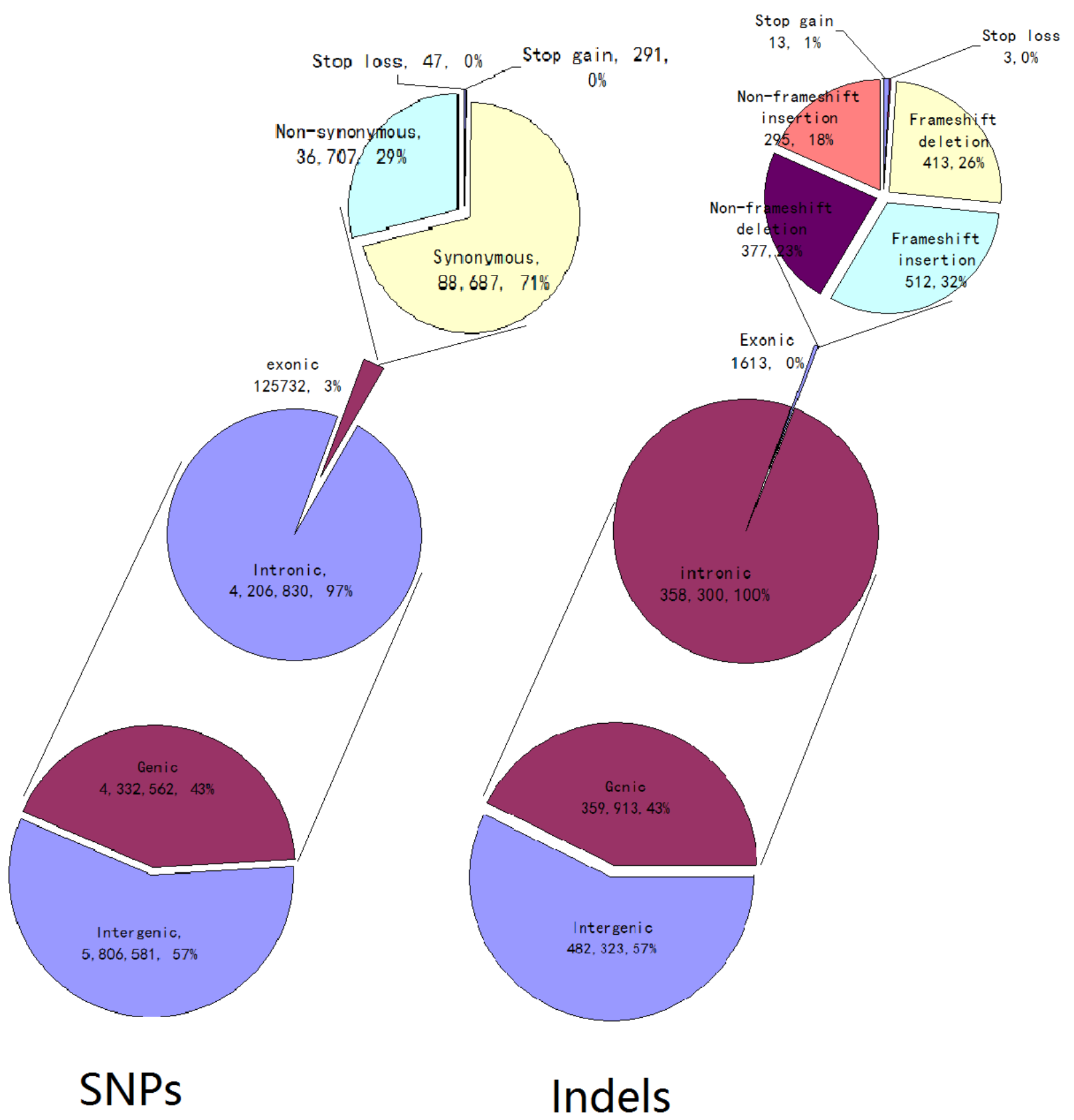

Figure 1. Annotation and distribution of single nucleotide polymorphisms and insertion/deletion polymorphisms

\section{Potential independent signatures of selection in guangxi three-yellow chicken}

Domestic animals were excellent models for genetic studies of phenotypic evolution (Andersson, 2001). They evolved genetic adaptations to new environments and were subjected to long-term artificial selections (Rubin et al., 2010). As a result of this process, marks in the proximity of genes influencing breed-defining traits were reduced levels of variability, and showed specific selection signature, including high population differentiation, greatly reduced variation, temporary increase in linkage disequilibrium, skewed allele frequency, and long-ranged haplotype homozygosity (Kaplan et al., 1989; Fay and Wu 2000; Kim and Stephan 2002; Kim and Nielsen 2004; Pollinger et al., 2005; Smith and Haigh, 2007). Selective sweep drew much attention, and a number of statistical tests, mostly based on summed statistics such as the tests by Lewontin and Krakauer (1973), Li et al. (1985), Tajima 
(1989), McDonald and Kreitman (1991), Fu and Li (1993), Fu (1997), Fay and Wu (2000) and Sabeti et al. (2002). Recently, the commonly used method was H-based heterozygosity of SNPs and Fst-based genetic diversification (Rubin et al., 2012). To accurately detect the genomic footprints left by selection in the GX-TYC, a selective sweep screen was performed by searching for genomic regions with high degrees of fixation. The pooled heterozygosity $\mathrm{Hp}$ was calculated, in sliding $200-\mathrm{Kb}$ windows crossing the chromosomes from sequence reads that correspond to the most and least frequently observed alleles at all SNP positions. The distribution of observed $\mathrm{Hp}$ values and the $\mathrm{Z}$ transformations of $\mathrm{Hp}$ and $\mathrm{ZHp}$ were marked in the Figure 2. The putative sweeps on those reaching a ZHp score of -5 or less were mainly described, as they are in the lower end of the distribution. In the genome-wide screen, only about $0.45 \%$ of windows $(n=46)$ showed a $\mathrm{Z}$ score of heterozygosity (ZHp) lower than -5 (Figure 2 and supplementary table 3 ). Striking selection signatures were mainly found on the SSC5, SSC8 and SSCZ regions (Figure 2), while some windows that did not reach the significance threshold may have contributed significantly to chicken domestication. The strongest signature of selection $(\mathrm{ZHp}=-17.158)$ was observed at 2.20 to $2.24 \mathrm{Mbs}$ on the chromosome 5, which included two genes, for instance SLC6A5 (Solute Carrier family 6, member 5) and NELL1 (neural EGFL like 1). The SLC6A5 gene encodes a sodium- and chloridedependent glycine neurotransmitter transporter, which is an important glycoprotein for scavenging extracellular glycine in glycine-mediated neurotransmission. Mutation in this gene can cause hyperekplexia. The neural EGFL like (NELL) gene encoded a cytoplasmic protein that contained epidermal growth factor (EGF) -like repeats. The protein may be involved in cell growth regulation and differentiation in a variety of tissues, including heart muscle, skeletal muscle and blood vessels, and may promote osteoblast cell differentiation and terminal mineralization (Bokui et al., 2008). The NELL1 gene was identified in a selective sweep in broilers (Elferink et al., 2012). The biological functions of NELL1 may be related to the selection on the muskuloskeletal integrity in modern broiler chickens. Bone integrity was likely to be coselected with growth rate and meat yield, as the skeleton of modern broilers needed to support a heavier weight (Zhou et al., 2007). The second convincing signature of selection $(\mathrm{ZHp}=-14.043)$ occurred on the sex chromosome $\mathrm{Z}$ that harbored the death-associated Protein Kinase 1 (DAPK1), cathepsin L2 (CTSL2), fructose-1,6bisphosphatase 2 (FBP2) and fructose-1,6-bisphosphatase 1 (FBP1). Death-associated Protein Kinase 1 gene is a calmodulin-dependent serine-threonine kinase involved in a variety of cell signaling pathways that regulate cell survival, apoptosis and autophagy. Cathepsin L2, a lysosomal cysteine proteinase, has been shown to be particularly powerful in degrading myofibrillar components in post-mortem autolysis. In fish muscles, CTSL2 exhibits heat-stability on 50 to $60^{\circ} \mathrm{C}$, and can degrade surimi protein during the manufacturing of silver carp surimi products ( $\mathrm{Li}$ et al., 2008). fructose-1,6bisphosphatase 1 that acts as a rate-limiting enzyme in gluconeogenesis, catalyzes the hydrolysis of fructose 1,6bisphosphate to fructose 6-phosphate, and inorganic phosphate in the presence of divalent cations, and mediates in gluconeogenesis and carbohydrate biosynthesis. fructose-1,6-bisphosphatase deficiency is associated with hypoglycemia and metabolic acidosis. FBP1 and FBP2 are two important paralogs. Although there is a strong selective signature on chromosome 8 , it was impossible to annotated any genes on it.

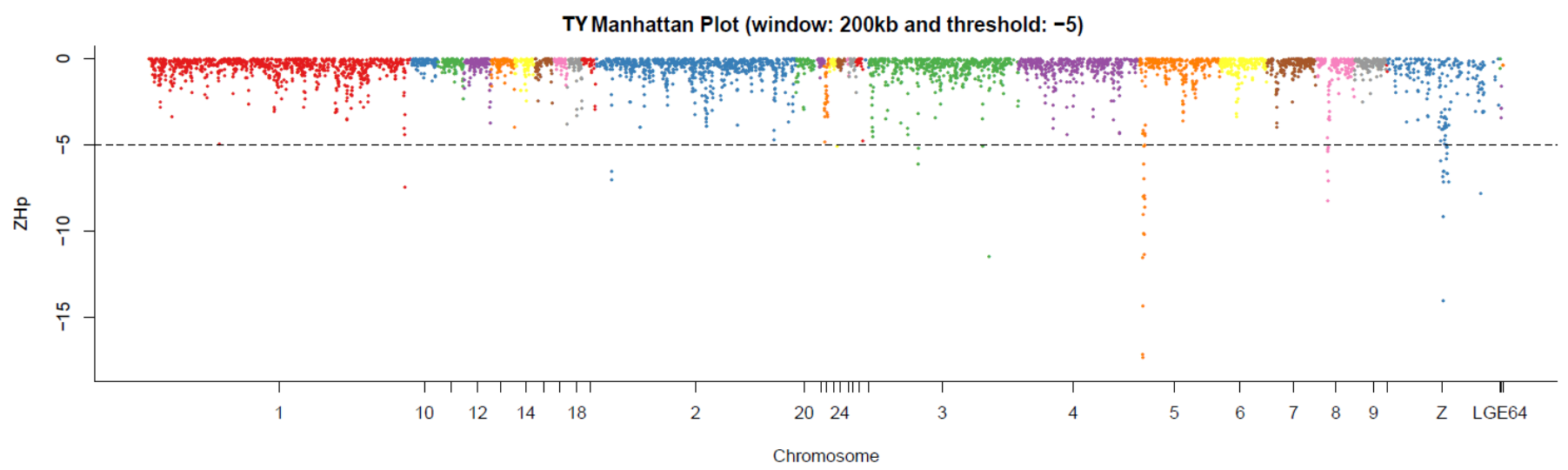

Figure 2. Genome-wide $\mathrm{Z}$ score of heterozygosity (ZHp) distribution. The $\mathrm{Y}$ axis is $\mathrm{ZHp}$ and the $\mathrm{X}$ axis shows positions of windows along each chromosome. Dotted lines indicate the thresholds with $\mathrm{ZHp}=-5$. 


\section{Gene Ontology and Kyoto Encyclopedia of Genes and Genome pathways analyses}

A total of 55 genes were identified in the regions that were considered to be positively selected (Supplementary table 3). Analysis of gene enrichment within this set of genes showed that, in biological-process (BP), significant enrichment for genes was primarily concentrated on the acid and anion transport, the hexos and monosaccharide metabolisms, the mesonephric development, and the defense response, whereas in cellular-component (CC) enrichment was potentially in cell periphery, plasma membrane and interleukin-28 receptor complex. In molecular-function (MF), enrichment was mainly concentrated on several sugar phosphatase activities and on rRNA (cytosine) methyltransferase activity (Figure 3 and Supplementary table 4). As gene enrichment analysis may yield high false-positive rates (Pavlidis et al., 2012), additional functional and physiological experiments were needed to verify the contribution of these genes to these processes. KEGG analysis identified eight pathways retaining a statistical significance $(P<0.05)$, i.e. Hedehog signaling pathway ( 3 genes, $P=0.0017$ ), pentose phosphate pathway ( 2 genes, $P=0.0059$ ), fructose and mannose metabolism ( 2 genes, $P=0.012$ ), valine, leucine and isoleucine degradation ( 2 genes, $P=0.020)$, insulin signaling pathway ( 3 genes, $P=0.022$ ), Fanconi anemia pathway ( 2 genes, $P=0.026$ ), glycolysis/gluconeogenesis ( 2 genes, $P=0.028$ ), as well as synthesis and degradation of ketone bodies ( 1 gene, $P=0.049$ ) (Figure 4, table 1 and Supplementary table 5). Most of these pathways were related to carbohydrate, lipid and amino acid metabolisms, while some were involved in processing genetic information and environmental information (Table 1).

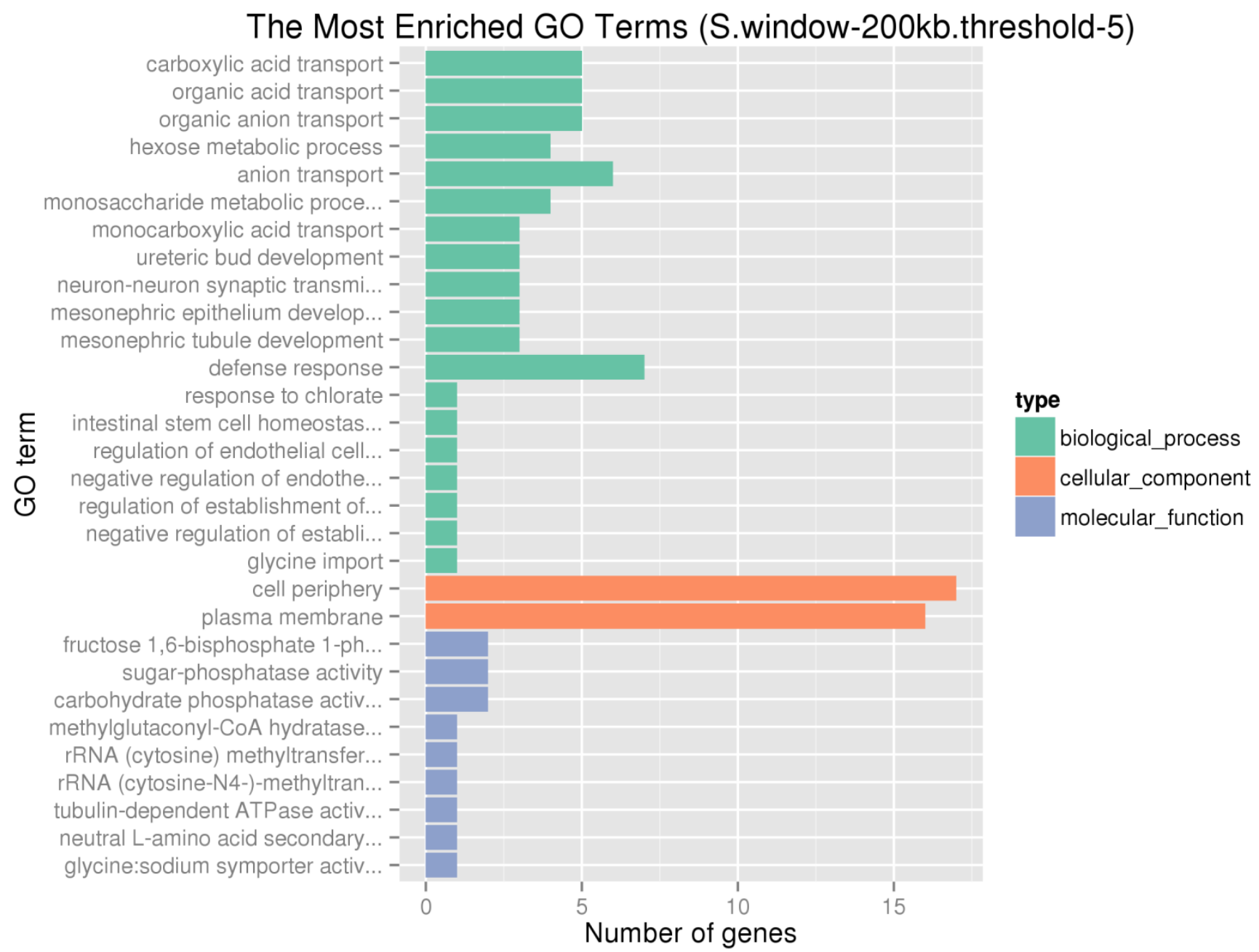

Figure 3. The most enriched gene ontology terms within significant selection of genes on Guangxi Three-yellow chicken of the present study. 


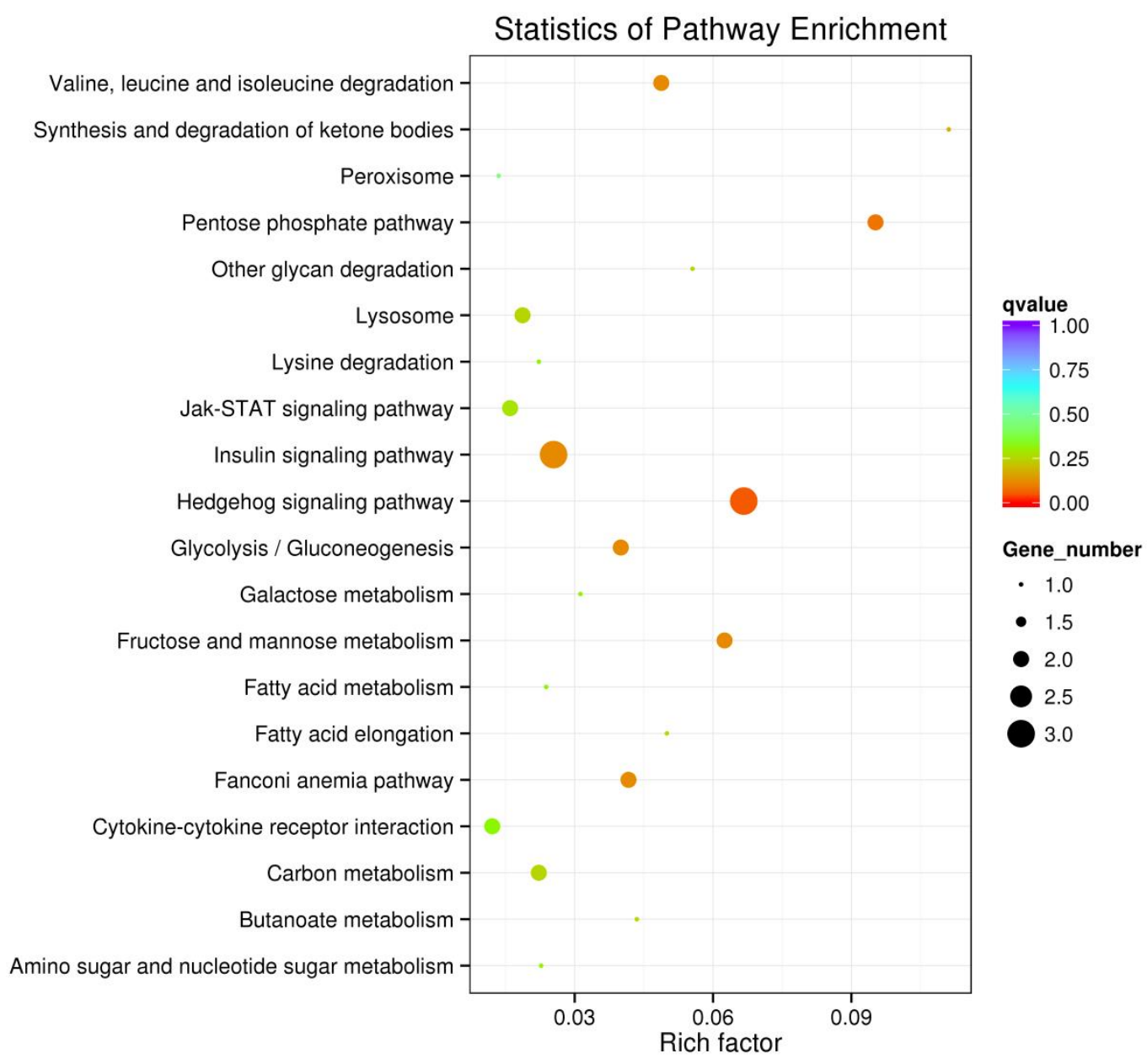

Figure 4. The 20 most enriched Kyoto Encyclopedia of Genes and Genome pathways within significant selection of genes on Guangxi three-yellow chicken in the present study.

Table 1. Results of Kyoto encyclopedia of genes and genome pathways analysis

\begin{tabular}{l|l|l|l}
\hline ID & KEGG Term & Gene & P-Value \\
\hline $\begin{array}{l}\text { Environmental information processing } \\
\text { Gga 04340 }\end{array}$ & Hedgehog signaling pathway & GAS1, Novel, PTCH1 & $1.78 \mathrm{E}-03$ \\
\hline $\begin{array}{l}\text { Carbohydrate metabolism } \\
\text { Gga 00030 }\end{array}$ & Pentose phosphate pathway & & \\
$\begin{array}{l}\text { Gga 00051 } \\
\text { Gga 00010 }\end{array}$ & Fructose and mannose metabolism & FBP1, FBP2 & $5.90 \mathrm{E}-03$ \\
\hline $\begin{array}{l}\text { Amino acid metabolism } \\
\text { Gga 00280 }\end{array}$ & FBP1, FBP2 & $1.26 \mathrm{E}-02$ \\
$\begin{array}{l}\text { Organismal systems-Endocrine systems } \\
\text { Gga 04910 }\end{array}$ & FBP1, FBP2 & $2.82 \mathrm{E}-02$ \\
\hline $\begin{array}{l}\text { Genetic information processing } \\
\text { Gga 03460 }\end{array}$ & Fanconi anemia pathway & HMGCL, AUH & $1.97 \mathrm{E}-02$ \\
\hline $\begin{array}{l}\text { Lipid metabolism } \\
\text { Gga 00072 }\end{array}$ & Synthesis and degradation of ketone bodies & FBP2, SHC2 & $2.29 \mathrm{E}-02$ \\
\hline
\end{tabular}

Three genes, i.e. the growth arrest-specific gene-1 (GAS1), Novel and protein patched homolog-1 (PTCH1), were enriched on the Hedgehog (Hh) signaling pathway that has many roles in development, cell proliferation, tissue patterning and stem cell maintenance. As a putative tumor suppressor gene (Del et al., 1992; Del et al., 1994; Atsumi et al., 2014), Growth arrest-specific 1(GAS1) inhibits cell replication by blocking the entry into the $\mathrm{S}$ 
phase of the cell cycle (Del et al., 1992). Protein patched homolog 1 (PTCH1) was a member of the patched gene family, and was the receptor for sonic hedgehog (SHH), which was a secreted molecule implicated in the formation of embryonic structures, and in tumorigenesis (Carpenter et al., 1998). PTCH1 prevented cells from growing and dividing in the absence of $\mathrm{SHH}$, thus it was considered as a tumor suppressor (Villavicencio et al., 2000), although it stoped suppressing cell proliferation in the presence of SHH.Fanconi anemia group $\mathrm{F}$ (FANCF) and Fanconi anemia group C (FANCC) belonged to the Fanconi anemia (FA) family, which contained of 22 genes whose protein products form a complex to participate in the efficient repair of damaged DNA (Nepal et al., 2017; Nalepa and Clapp, 2018; Tsui and Crismani, 2019). FANCF stabilized the FANCC/FANCE sub complex and the FANCA/FANCG subcomplex, and locked the whole FA core complex in a conformation that was essential for DNA repair (Leveille et al., 2004), suggesting its important role in maintaining the cell's genomic integrity (Medhurst et al., 2001). FANCF-deficient mice found with no germ cells in the seminiferous tubules, and no or almost no primordial follicles in the ovaries (Bakker et al., 2012). As a mitochondrial enzyme, 3-Hydroxymethyl-3Methylglutaryl-CoA Lyase (HMGCL) was involved in the valine, leucine and isoleucine degradation and synthesis as well as in the degradation of ketone bodies. When glucose is not available, such as during fasting, ketones are the compounds used for energy by certain organs and tissues, particularly the brain. In human, HMGCL deficiency, often as an autosomal recessive mitochondrial disease (Lin et al., 2009), usually presented with acute episodes of vomiting, hypotonia, hypoketotic, hypoglycemia metabolic acidosis and hyperammonemia in infancy. In the valine, leucine and isoleucine degradation pathways, 3-methylglutaconyl-CoA hydratase (AUH) was another selected gene encoding a bifunctional mitochondrial protein that had both RNA-binding and hydratase activities. The protein can catalyze the transformation of 3-methylglutaconyl-CoA to 3-hydroxy3-methyl-glutaryl-CoA, and binds AU-rich elements found in the 3'-untranslated regions of rapidly decaying mRNAs. Decreased levels of AUH also leaded to a slower cell growth. Reduced or elevated levels of AUH can lead to defects in mitochondrial translation, ultimately leading to changes in decreased RNA stability as well as in the mitochondrial morphology, biogenesis and respiratory function (Mack et al., 2006). FBP1 and FBP2 were enriched in pentose phosphate pathway, in fructose and mannose metabolism, in glycolysis/gluconeogenesis, and in insulin signaling pathway that regulates carbohydrate metabolism and endocrine systems. The pentose phosphate pathway is a glucose metabolism process that produces reduced Nicotinamide Adenine Dinucleotide Phosphate and pentoses, which is an essential part of histidine and purine/pyrimidine biosynthesis nucleotides. Glycolysis/ gluconeogenesis is the process of converting glucose to pyruvate and producing small amounts of ATP (energy) and NADH (reducing power). FBPs ultimately control the rate of gluconeogenesis, whereas the insulin signaling pathway is responsible for regulation of glucose and lipid metabolism, besides many other functions such as regulation of cell proliferation in response to mitogens. Src homology 2 domain containing-transforming protein 2 (SHC2), as a substrate of insulin receptor, can activate the RAS/MAPK pathway independently of IRS-1 (Taha and Klip, 1999; Ferguson et al., 2014). Of the ten genes enriched in the aforementioned pathways, FBP1, FBP2, SHC3, FANCC and PTCH1 were located on the 41.2 to 43.3 region of chromosome $\mathrm{Z}$, which might be integrally chained due to selected certain particular genes, with FBP1 and FBP2 being the most likely objectives and the others likely being jointly selected. Within the selective sweeps in all of the domestic chickens in the present and other studies (Rubin et al., 2010), some of the genes were also found to be associated with domestication traits in chickens and other farmed animals, which reinforced their important roles in chicken domestication. For instance, $\mathrm{BCDO} 2$ was found to be associated with the yellow skin (Eriksson et al., 2008). However, this gene in GX-TYC was not detected. ESRP2 is associated with chicken abdominal fat contents (Zhang et al., 2012), and NELL1 was identified in a selective sweep in the broilers (Elferink et al., 2012). In the present study, NELL1 gene was found to undergo a strong selection in GX-TYC, which verified GX-TYC as a broiler, thus conforming to the long-term breeding purpose of GX-TYC and confirming that the present approach and the resulting data were reliable.

\section{CONCLUSION}

In summary, herein a whole genome map of Single nucleotide polymorphisms (SNPs), insertion/deletion polymorphisms (InDels) of Guangxi Three-Yellow chicken (GX-TYC) were presented and some genetic footprints of its domestication were uncovered. These data provide important resources for further improvements of fowl breeding and for future studies on the molecular mechanisms of chicken phenotypic variations and certain diseases. 


\section{DECLARATIONS}

\section{Consent to publish}

All authors agree to publish this manuscript.

\section{Availability of data and materials}

All data have been presented in the manuscript as figures and tables and as the supplementary data. There is no additional data and materials.

\section{Competing interests}

All authors claim that there is no completing interest concerned.

\section{Funding}

This work was supported by Guangxi Provincial Natural Science Foundation of China (NO. 2013GXNSFDA019013) to Dr. Yuying Liao. Guangxi Special Fund for Specially-invited Expert.

\section{Authors' contributions}

YL drafted the manuscript. YL and DJL formulated the concepts. JS, YH, FW and GM analyzed the data and prepared the figures and tables. LZ performed English editing of the manuscript. DJL finalized the manuscript.

\section{Acknowledgements}

We would like to think Dr. Fred Bogott at the Medical Center, Austin of Minnesota for his excellent English editing of the manuscript.

\section{REFERENCES}

Andersson L (2001). Genetic dissection of phenotypic diversity in farm animals. Nature Reviews Genetics, 2: 130-138. DOI: http://www.doi.org/10.1038/35052563

Atsumi T, Singh R, Sabharwal L, Bando H, Meng J, Arima Y, Yamada M, Harada M, Jiang JJ, Kamimura D et al. (2014). Inflammation amplifier, a new paradigm in cancer biology. Cancer Research, 74: 8-14. DOI: http://www.doi.org/ 10.1158/0008-5472.CAN-13-2322

Bakker ST, Van de Vrugt HJ, Visser JA, Delzenne-Goette E, Van der Wal A, Berns MA, Van V, Oostra AB, de VS, Kramer P et al. (2012). Fancf-deficient mice are prone to develop ovarian tumours. The Journal of Pathology, 226: 28-39. DOI: https://doi.org/10.1002/path.2992

Bokui N, Otani T, Igarashi K, Kaku J, Oda M, Nagaoka T, Seno M, Tatematsu K, Okajima T, Matsuzaki T, Ting K, Tanizawa K Kuroda $S$ et al. (2008). Involvement of MAPK signaling molecules and Runx2 in the NELL1-induced osteoblastic differentiation. FEBS Letters, 582: 365-371. DOI:https://doi.org/10.1016/j.febslet.2007.12.006

Carpenter D, Stone DM, Brush J, Ryan A, Armanini M, Frantz G, Rosenthal A and de Sauvage FJ (1998). Characterization of two patched receptors for the vertebrate hedgehog protein family. Proceedings of the National Academy of Sciences of the United States of America, 95: 13630-13634. DOI:https://doi.org/10.1073/pnas.95.23.13630.

Del SG, Collavin L, Ruaro ME, Edomi P, Saccone S, Valle GD and Schneider C (1994). Structure, function, and chromosome mapping of the growth-suppressing human homologue of the murine gas1 gene. Proceedings of the National Academy of Sciences of the United States of America, 91: 1848-1852. DOI:https://doi.org/10.1073/pnas.91.5.1848.

Del SG, Ruaro ME, Philipson L and Schneider C (1992). The growth arrest-specific gene, gas1, is involved in growth suppression. Cell, 70: 595-607. DOI:https://doi.org/10.1016/0092-8674(92)90429-g.

Elferink MG, Megens HJ, Vereijken A, Hu X, Crooijmans RP and Groenen MA (2012). Signatures of selection in the genomes of commercial and non-commercial chicken breeds. PLoS One, 7:e32720. DOI:https://doi.org/: 10.1371/journal.pone.0032720

Eriksson J, Larson G, Gunnarsson U, Bed'hom B, Tixier-Boichard M, Stromstedt L, Wright D, Jungerius A, Vereijken A, Randi E et al (2008). Identification of the yellow skin gene reveals a hybrid origin of the domestic chicken. PLoS Genetics, 4:e1000010. DOI: https://doi.org.10.1371/journal.pgen.1000010.

Fan WL, Ng CS, Chen CF, Lu MY, Chen YH, Liu CJ, Wu SM, Chen CK, Chen JJ, Mao CT et al. (2013). Genome-wide patterns of genetic variation in two domestic chickens. Genome Biology and Evolution, 5:1376-1392. DOI:https://doi.org.10.1093/gbe/evt097.

Fay JC and Wu CI (2000). Hitchhiking under positive Darwinian selection. Genetics, 155:1405-1413. DOI:https://doi.org.10,1002/1098-2272(200007)19:1<81::AIDGEPI6>3.0.CO;2-8

Ferguson MC, Garland EM, Hedges L, Womack-Nunley B, Hamid R, Phillips JA, III, Shibao CA, Raj SR, Biaggioni I and Robertson D (2014). SHC2 gene copy number in multiple system atrophy (MSA). Clinical Autonomic Research, 24: 25-30. DOI:https://doi.org.10.1007/s10286-013-0216-8.

Fu YX (1997). Statistical tests of neutrality of mutations against population growth, hitchhiking and background selection. Genetics, 147: 915-925. PMID:9335623.

Fu YX and Li WH (1993). Statistical tests of neutrality of mutations. Genetics, 133: 693-709. PMID:8454210.

Huang dW, Sherman BT and Lempicki RA (2009). Systematic and integrative analysis of large gene lists using DAVID bioinformatics resources. Nature Protocols, 4: 44-57. DOI:https://doi.org.10.1038/nprot.2008.211.

Kaplan NL, Hudson RR and Langley CH (1989). The "hitchhiking effect" revisited. Genetics, 123: 887-899. DOI:https://doi.org.10.1101/gad.3.12b.2218.

Kim Y and Nielsen R (2004). Linkage disequilibrium as a signature of selective sweeps. Genetics, 167: 1513-1524. DOI:https://doi.org.10.1534/genetics.103.025387.

Kim Y and Stephan W (2002). Detecting a local signature of genetic hitchhiking along a recombining chromosome. Genetics, 160: 765777. DOI:https://doi.org.10.3410/f.1008369.104907.

Leveille F, Blom E, Medhurst AL, Bier P, Laghmani EH, Johnson M, Rooimans MA, Sobeck A, Waisfisz Q, Arwert F et al. (2004). The Fanconi anemia gene product FANCF is a flexible adaptor protein. the Journal of Biological Chemistry, 279: 39421-39430. DOI:https://doi.org.10.1074/jbc.M407034200.

Lewontin RC and Krakauer J (1973). Distribution of gene frequency as a test of the theory of the selective neutrality of polymorphisms. Genetics, 74:175-195. PMID:4711903.

Li H and Durbin R (2009). Fast and accurate short read alignment with Burrows-Wheeler transform. Bioinformatics, 25: 1754-1760. DOI:https://doi.org.10. 1093/bioinformatics/btp324.

Li S, Zhou X, Zhang N, Liu H and Ma C (2008). Purification and characterisation of cathepsin L2 from dorsal muscle of silver carp (Hypophthalmichthys molitrix). Food Chemistry, 111: 879-886. DOI:https://doi.org.10. 1016/j.foodchem.2008.04.072.

Li WH, Wu CI and Luo CC (1985). A new method for estimating synonymous and nonsynonymous rates of nucleotide substitution considering the relative likelihood of nucleotide and codon changes. 
Molecular Biology and Evolution, 2: 150-174. DOI:https://doi.org.10. 1093/oxfordjournals.molbev.a040343.

Lin WD, Wang CH, Lai CC, Tsai Y, Wu JY, Chen CP and Tsai FJ (2009). Molecular analysis of Taiwanese patients with 3-hydroxy3-methylglutaryl CoA lyase deficiency. Clinica Chimica Acta, 401: 33-36. DOI:https://doi.org.10.1016/j.cca.2008.11.004.

Mack M, Schniegler-Mattox U, Peters V, Hoffmann GF, Liesert M, Buckel W and Zschocke J (2006). Biochemical characterization of human 3-methylglutaconyl-CoA hydratase and its role in leucine metabolism. The FEBS Journal, 273: 2012-2022. DOI:https://doi.org.10. 1111/j.1742-4658.2006.05218.x.

McDonald JH and Kreitman M (1991). Adaptive protein evolution at the Adh locus in Drosophila. Nature, 351: 652-654. DOI:https://doi.org.10.1038/351652a0.

Medhurst AL, Huber PA, Waisfisz Q, de Winter JP and Mathew CG (2001). Direct interactions of the five known Fanconi anaemia proteins suggest a common functional pathway. Human Molecular Genetics, 10: 423-429. DOI:https://doi.org.10.1093/hmg/10.4.423.

Nalepa G and Clapp DW (2018). Fanconi anaemia and cancer: an intricate relationship. Nature Reviews Cancer 18: 168-185. DOI:https://doi.org.10.1038/nrc.2017.116.

Nepal M, Che R, Zhang J, Ma C and Fei P (2017). Fanconi Anemia Signaling and Cancer. Trends in Cancer, 3: 840-856. DOI:https://doi.org.10.1016/j.trecan.2017.10.005.

Pavlidis P, Jensen JD, Stephan W and Stamatakis A (2012). A critical assessment of storytelling: gene ontology categories and the importance of validating genomic scans. Molecular Biology and Evolution, 29: 3237-3248. DOI:https://doi.org.10.1093/molbev/mss136.

Pollinger JP, Bustamante CD, Fledel-Alon A, Schmutz S, Gray MM and Wayne RK (2005). Selective sweep mapping of genes with large phenotypic effects. Genome Research, 15: 1809-1819. DOI:https://doi.org.10.1101/gr.4374505.

Rubin CJ, Megens HJ, Martinez BA, Maqbool K, Sayyab S, Schwochow D, Wang C, Carlborg O, Jern P, Jorgensen CB et. al. (2012). Strong signatures of selection in the domestic pig genome. Proceedings of the National Academy of Sciences of the United States of America, 109: 19529-19536. DOI:https://doi.org.10.1073/pnas.1217149109.

Rubin CJ, Zody MC, Eriksson J, Meadows JR, Sherwood E, Webster MT, Jiang L, Ingman M, Sharpe T, Ka S et al. (2010). Wholegenome resequencing reveals loci under selection during chicken domestication. Nature, 464: 587-591. DOI:https://doi.org.10. 1038/nature08832.

Sabeti PC, Reich DE, Higgins JM, Levine HZ, Richter DJ, Schaffner SF, Gabriel SB, Platko JV, Patterson NJ, McDonald GJ et al. (2002). Detecting recent positive selection in the human genome from haplotype structure. Nature, 419: 832-837. DOI:https://doi.org.10.1038/nature01140.

Smith JM and Haigh J (2007). The hitch-hiking effect of a favourable gene. Genetical Research, 89: 391-403. DOI:https://doi.org.10.1017/S0016672308009579.

Taha C and Klip A (1999). The insulin signaling pathway. The Journal of Membrane Biology, 169: 1-12. DOI:https://doi.org.10. 1007/p100005896.

Tajima F (1989). Statistical method for testing the neutral mutation hypothesis by DNA polymorphism. Genetics, 123:585-595. PMID:2513255.

Tsui V and Crismani W (2019). The Fanconi Anemia Pathway and Fertility. Trends in Genetics, 35: 199-214. DOI:https://doi.org.10.1016/j.tig.2018.12.007.

Villavicencio EH, Walterhouse DO and Iannaccone PM (2000). The sonic hedgehog-patched-gli pathway in human development and disease. American Journal of Human Genetics, 67: 1047-1054. DOI:https://doi.org.10.1016/S0002-9297(07)62934-6.

Wang K, Li M and Hakonarson H (2010). ANNOVAR: functional annotation of genetic variants from high-throughput sequencing data. Nucleic Acids Research, 38: e164. DOI:https://doi.org.10.1093/nar/gkq603.

Wei FY, Wu Q, Deng JX, Yang FJ, Chen X, Chen JP and Zhu CS (2019). The breeding and industrialization of San yellow chicken in Guangxi. Poultry Husbandry and Disease Control, 5: 10-25. Available at: https://kns.cnki.net/KCMS/detail/detail.aspx?dbcode=CJFQ\&dbna me $=$ CJFDLAST2020\&filename $=$ YQYF201905004\&v=MDg4NDR 1eFITNORoMVQzcVRyV00xRnJDVVI3cWZZT1JwRnlqbFZyckF QRHpTYUxHNEg5ak1xbzlGWUISOGVYMUw=.

Wong GK, Liu B, Wang J, Zhang Y, Yang X, Zhang Z, Meng Q, Zhou J, Li D, Zhang J et al. (2004). A genetic variation map for chicken with 2.8 million single-nucleotide polymorphisms. Nature, 432: 717-722. DOI:https://doi.org.10.1038/nature03156.

Zhang H, Hu X, Wang Z, Zhang Y, Wang S, Wang N, Ma L, Leng L, Wang S, Wang Q et. al. (2012). Selection signature analysis implicates the PC1/PCSK1 region for chicken abdominal fat content. PLoS One, 7: 40736. DOI:https://doi.org.10.1371/journal.pone.0040736.

Zheng PL, Zhang ZG, Chen XH, Tu YR, Cheng ST, Xu ZY,Chen LF, Zhang SY, Li G, Yu DX et. al. (1989). Poultry Breeds in China.

Zhou H, Deeb N, Evock-Clover CM, Mitchell AD, Ashwell CM and Lamont SJ (2007). Genome-wide linkage analysis to identify chromosomal regions affecting phenotypic traits in the chicken. III. Skeletal integrity. Poultry Science, 86: 255-266. DOI:https://doi.org/10.1093/ps/86.2.255. 


\section{Supplementary Data}

$\underline{\text { Supplementary Table 1. Summary and annotation of single nucleotide polymorphisms in Guangxi three-yellow chickens }}$

\begin{tabular}{l|lc} 
Category & & Number of SNPs \\
\hline Upstream & Stop gain & 140,563 \\
& Stop loss & 291 \\
& Synonymous & 47 \\
Exonic & Non-synonymous & 88,687 \\
& Unknowns & 36,707 \\
& & 0 \\
Intronic & & $3,938,603$ \\
Splicing & & 387 \\
Downstream & & 122,273 \\
Upstream/downstream & & 5,004 \\
Intergenic & & $5,806,581$ \\
\hline Total & & $10,139,143$ \\
\hline
\end{tabular}

Supplementary Table 2. Summary and annotation of Indels in Guangxi three-yellow chickens

\begin{tabular}{l|lc}
\hline \multicolumn{1}{c}{ Category } & & Number of Indels \\
\hline Upstream & Stop gain & 10632 \\
& Stop loss & 13 \\
& Frameshift deletion & 3 \\
Exonic & Frameshift insertion & 413 \\
& Non-frameshift deletion & 512 \\
& Non-frameshift insertion & 377 \\
Intronic & & 295 \\
Splicing & & 335096 \\
Downstream & & 175 \\
Upstream/Downstream & 11948 \\
Intergenic & & 418 \\
Insertion & & 482323 \\
Deletion & & 380249 \\
Het Rate (\%) & & 461987 \\
Total & & 0.643 \\
\hline
\end{tabular}


Supplementary Table 3. Detail information of single nucleotide polymorphisms loci with ZHp $\leq-5$

\begin{tabular}{|c|c|c|c|c|}
\hline Ensembl Gene ID & ZHp & CHROM & Start & Gene \\
\hline ENSGALG00000003958 & -11.572 & 5 & 2129860 & $\underline{\text { PRMT3 }}$ \\
\hline ENSGALG00000003908 & -17.158 & 5 & 2204843 & $\underline{\text { SLC6A5 }}$ \\
\hline ENSGALG00000003777 & -17.158 & 5 & 2243366 & $\underline{\text { NELL1 }}$ \\
\hline ENSGALG00000003748 & -9.0503 & 5 & 2760128 & $\underline{\text { ANO5 }}$ \\
\hline ENSGALG00000003660 & -10.144 & 5 & 2946165 & $\underline{\text { FANCF }}$ \\
\hline ENSGALG00000003655 & -10.144 & 5 & 2976276 & $\underline{\text { GAS2 }}$ \\
\hline ENSGALG00000003648 & -6.1477 & 5 & 3060193 & $\underline{\text { SVIP }}$ \\
\hline ENSGALG00000013311 & -6.9695 & 5 & 3278760 & $\underline{\mathrm{ANO} 3}$ \\
\hline ENSGALG00000013304 & -11.351 & 5 & 3407884 & $\underline{\text { SLC5A12 }}$ \\
\hline ENSGALG00000023904 & -11.351 & 5 & 3505528 & $\underline{\text { FIBIN }}$ \\
\hline ENSGALG00000013297 & -11.351 & 5 & 3530348 & $\underline{B B O X 1}$ \\
\hline ENSGALG00000012194 & -10.236 & 5 & 3627318 & $\underline{\mathrm{CCDC} 34}$ \\
\hline ENSGALG00000012191 & -8.6053 & 5 & 3651822 & $\underline{\mathrm{LGR} 4}$ \\
\hline ENSGALG00000012170 & -8.6053 & 5 & 3717817 & $\underline{\text { LIN7B }}$ \\
\hline ENSGALG00000012163 & -8.6053 & 5 & 3757392 & $\underline{B D N F}$ \\
\hline ENSGALG00000012162 & -8.6053 & 5 & 3783967 & $\underline{\text { Novel }}$ \\
\hline ENSGALG00000012160 & -8.137 & 5 & 3878424 & $\underline{\text { KIF18A }}$ \\
\hline ENSGALG00000012153 & -5.0344 & 5 & 3921314 & $\underline{\text { METTL15 }}$ \\
\hline ENSGALG00000004112 & & 23 & 5552378 & $\underline{\text { FUCA1 }}$ \\
\hline ENSGALG00000004120 & & 23 & 5558027 & $\underline{\mathrm{CNR} 2}$ \\
\hline ENSGALG00000003971 & & 23 & 5518731 & $\underline{\text { TCEB3 }}$ \\
\hline ENSGALG00000004002 & & 23 & 5540404 & $\underline{\text { LYPLA2 }}$ \\
\hline ENSGALG00000004047 & & 23 & 5545884 & $\underline{\text { GALE }}$ \\
\hline ENSGALG00000003936 & -5.0735 & 23 & 5514567 & $\underline{\text { PPT1 }}$ \\
\hline ENSGALG00000004268 & & 23 & 5696766 & $\underline{\text { NIPAL3 }}$ \\
\hline ENSGALG00000004155 & & 23 & 5586447 & $\underline{\text { MYOM3 }}$ \\
\hline ENSGALG00000003879 & & 23 & 5493121 & $\underline{\text { MFSD2A }}$ \\
\hline ENSGALG00000004141 & & 23 & 5581470 & $\underline{\text { LBFABP }}$ \\
\hline ENSGALG00000004057 & & 23 & 5548630 & HMGCL \\
\hline
\end{tabular}




\begin{tabular}{|c|c|c|c|c|}
\hline ENSGALG00000004122 & & 23 & 5565578 & $\underline{\text { PNRC2 }}$ \\
\hline ENSGALG00000004249 & & 23 & 5643857 & $\underline{\text { GRHL3 }}$ \\
\hline ENSGALG00000003986 & & 23 & 5536714 & PITHD1 \\
\hline ENSGALG00000004133 & & 23 & 5572421 & $\underline{\text { SRSF10 }}$ \\
\hline ENSGALG00000004231 & & 23 & 5625795 & $\underline{\text { IFNLR1 }}$ \\
\hline ENSGALG00000004221 & & 23 & 5618293 & $\underline{\text { IL22RA1 }}$ \\
\hline ENSGALG00000003912 & & 23 & 5502015 & $\underline{\text { CAP1 }}$ \\
\hline ENSGALG00000017658 & -6.8264 & $\mathrm{Z}$ & 40920596 & GAS1 \\
\hline ENSGALG00000026583 & -6.8264 & $\mathrm{Z}$ & 40920611 & $\underline{\text { Novel }}$ \\
\hline ENSGALG00000012608 & -14.043 & $\mathrm{Z}$ & 41139762 & $\underline{\text { DAPK1 }}$ \\
\hline ENSGALG00000012610 & -14.043 & $\mathrm{Z}$ & 41267496 & $\underline{\text { CTSL2 }}$ \\
\hline ENSGALG00000012612 & -14.043 & $\mathrm{Z}$ & 41282076 & $\underline{\text { FBP2 }}$ \\
\hline ENSGALG00000012613 & -14.043 & $\mathrm{Z}$ & 41306732 & $\underline{\text { FBP1 }}$ \\
\hline ENSGALG00000012615 & -7.1684 & Z & 41350384 & $\underline{\text { C9orf3 }}$ \\
\hline ENSGALG00000012618 & -7.1684 & Z & 41521328 & $\underline{\text { FANCC }}$ \\
\hline ENSGALG00000012620 & -6.5791 & Z & 41632373 & $\underline{\text { PTCH1 }}$ \\
\hline ENSGALG00000010683 & -5.8349 & Z & 43300329 & $\underline{\text { S1PR3 }}$ \\
\hline ENSGALG00000010688 & -5.8349 & Z & 43311888 & $\underline{\mathrm{SHC} 3}$ \\
\hline ENSGALG00000010694 & -5.8349 & $\mathrm{Z}$ & 43414992 & $\underline{\text { SECISBP2 }}$ \\
\hline ENSGALG00000010697 & -5.8349 & $\mathrm{Z}$ & 43446316 & $\underline{\text { SEMA4D }}$ \\
\hline ENSGALG00000005323 & -5.1417 & $\mathrm{Z}$ & 43855798 & $\underline{\text { DIRAS2 }}$ \\
\hline ENSGALG00000015216 & -5.1608 & Z & 43939409 & $\underline{\mathrm{SYK}}$ \\
\hline ENSGALG00000015213 & -5.1608 & $\mathrm{Z}$ & 43980705 & $\underline{\text { TPPP2 }}$ \\
\hline ENSGALG00000021843 & -6.6507 & $\mathrm{Z}$ & 44067508 & $\underline{\mathrm{AUH}}$ \\
\hline ENSGALG00000015209 & -6.683 & $\mathrm{Z}$ & 44205924 & $\underline{\text { NFIL3 } 3}$ \\
\hline ENSGALG00000000151 & -7.1704 & $\mathrm{Z}$ & 45148296 & ADAMTS19 \\
\hline
\end{tabular}


Supplementary Table 4. Gene functional enrichment analysis of genes significant selection in Guangxi three-yellow chickens

\begin{tabular}{|c|c|c|c|c|}
\hline GO_accession & Term_type & Description & $\mathbf{N}$ & P Value \\
\hline GO:0042132 & MF & fructose 1,6-bisphosphate 1-phosphatase activity & 2 & $9.74 \mathrm{E}-06$ \\
\hline GO:0046942 & BP & carboxylic acid transport & 5 & $1.72 \mathrm{E}-04$ \\
\hline GO:0015849 & $\mathrm{BP}$ & organic acid transport & 5 & 1.77E-04 \\
\hline GO:0050308 & MF & sugar-phosphatase activity & 2 & 4.43E-04 \\
\hline GO:0019203 & MF & carbohydrate phosphatase activity & 2 & $5.40 \mathrm{E}-04$ \\
\hline GO:0015711 & $\mathrm{BP}$ & organic anion transport & 5 & $6.52 \mathrm{E}-04$ \\
\hline GO:0019318 & $\mathrm{BP}$ & hexose metabolic process & 4 & 7.37E-04 \\
\hline GO:0071944 & $\mathrm{CC}$ & cell periphery & 17 & 7.53E-04 \\
\hline GO:0006820 & $\mathrm{BP}$ & anion transport & 6 & $8.51 \mathrm{E}-04$ \\
\hline GO:0005996 & $\mathrm{BP}$ & monosaccharide metabolic process & 4 & $1.12 \mathrm{E}-03$ \\
\hline GO:0005886 & $\mathrm{CC}$ & plasma membrane & 16 & $1.48 \mathrm{E}-03$ \\
\hline GO:0015718 & $\mathrm{BP}$ & monocarboxylic acid transport & 3 & $2.05 \mathrm{E}-03$ \\
\hline GO:0001657 & $\mathrm{BP}$ & ureteric bud development & 3 & $2.60 \mathrm{E}-03$ \\
\hline GO:0007270 & $\mathrm{BP}$ & neuron-neuron synaptic transmission & 3 & $2.65 \mathrm{E}-03$ \\
\hline GO:0072163 & $\mathrm{BP}$ & mesonephric epithelium development & 3 & $2.69 \mathrm{E}-03$ \\
\hline GO:0072164 & $\mathrm{BP}$ & mesonephric tubule development & 3 & $2.69 \mathrm{E}-03$ \\
\hline GO:0006952 & $\mathrm{BP}$ & defense response & 7 & $2.71 \mathrm{E}-03$ \\
\hline GO:0004490 & MF & methylglutaconyl-CoA hydratase activity & 1 & $3.15 \mathrm{E}-03$ \\
\hline GO:0010157 & $\mathrm{BP}$ & response to chlorate & 1 & $3.15 \mathrm{E}-03$ \\
\hline GO:0016434 & MF & rRNA (cytosine) methyltransferase activity & 1 & $3.15 \mathrm{E}-03$ \\
\hline GO:0036335 & $\mathrm{BP}$ & intestinal stem cell homeostasis & 1 & $3.15 \mathrm{E}-03$ \\
\hline GO:0071424 & MF & rRNA (cytosine-N4-)-methyltransferase activity & 1 & $3.15 \mathrm{E}-03$ \\
\hline GO:0070463 & MF & tubulin-dependent ATPase activity & 1 & $3.15 \mathrm{E}-03$ \\
\hline GO: 1901550 & $\mathrm{BP}$ & regulation of endothelial cell development & 1 & $3.15 \mathrm{E}-03$ \\
\hline GO: 1901551 & $\mathrm{BP}$ & negative regulation of endothelial cell development & 1 & $3.15 \mathrm{E}-03$ \\
\hline GO: 1903140 & $\mathrm{BP}$ & regulation of establishment of endothelial barrier & 1 & $3.15 \mathrm{E}-03$ \\
\hline GO:1903141 & $\mathrm{BP}$ & negative regulation of establishment of endothelial barrier & 1 & $3.15 \mathrm{E}-03$ \\
\hline GO:0005294 & MF & neutral L-amino acid secondary active transmembrane transporter activity & 1 & $3.15 \mathrm{E}-03$ \\
\hline GO:0015375 & $\mathrm{MF}$ & glycine:sodium symporter activity & 1 & $3.15 \mathrm{E}-03$ \\
\hline GO:0036233 & $\mathrm{BP}$ & glycine import & 1 & $3.15 \mathrm{E}-03$ \\
\hline GO:1990379 & $\mathrm{BP}$ & lipid transport across blood brain barrier & 1 & $3.20 \mathrm{E}-03$ \\
\hline GO:0001823 & $\mathrm{BP}$ & mesonephros development & 3 & $3.21 \mathrm{E}-03$ \\
\hline GO:0046854 & $\mathrm{BP}$ & phosphatidylinositol phosphorylation & 2 & $3.51 \mathrm{E}-03$ \\
\hline GO:0032002 & $\mathrm{CC}$ & interleukin-28 receptor complex & 1 & $3.54 \mathrm{E}-03$ \\
\hline GO:0046834 & $\mathrm{BP}$ & lipid phosphorylation & 2 & $4.02 \mathrm{E}-03$ \\
\hline GO:0050747 & $\mathrm{BP}$ & positive regulation of lipoprotein metabolic process & 1 & $4.18 \mathrm{E}-03$ \\
\hline GO:1903061 & $\mathrm{BP}$ & positive regulation of protein lipidation & 1 & $4.18 \mathrm{E}-03$ \\
\hline GO:0006836 & BP & neurotransmitter transport & 3 & $4.30 \mathrm{E}-03$ \\
\hline GO:0005548 & MF & phospholipid transporter activity & 2 & $4.53 \mathrm{E}-03$ \\
\hline GO:0003978 & $\mathrm{MF}$ & UDP-glucose 4-epimerase activity & 1 & $4.53 \mathrm{E}-03$ \\
\hline GO:0005169 & $\mathrm{MF}$ & neurotrophin TRKB receptor binding & 1 & $5.14 \mathrm{E}-03$ \\
\hline GO:0061193 & $\mathrm{BP}$ & taste bud development & 1 & $5.14 \mathrm{E}-03$ \\
\hline
\end{tabular}




\begin{tabular}{|c|c|c|c|c|}
\hline GO:0045668 & BP & negative regulation of osteoblast differentiation & 2 & $5.15 \mathrm{E}-03$ \\
\hline GO:0061005 & $\mathrm{BP}$ & cell differentiation involved in kidney development & 2 & $5.53 \mathrm{E}-03$ \\
\hline GO:0051234 & $\mathrm{BP}$ & establishment of localization & 18 & $5.94 \mathrm{E}-03$ \\
\hline GO:0021997 & $\mathrm{BP}$ & neural plate axis specification & 1 & $6.29 \mathrm{E}-03$ \\
\hline GO:0097108 & MF & hedgehog family protein binding & 1 & $6.29 \mathrm{E}-03$ \\
\hline GO:2001013 & $\mathrm{BP}$ & epithelial cell proliferation involved in renal tubule morphogenesis & 1 & $6.29 \mathrm{E}-03$ \\
\hline GO:0010693 & $\mathrm{BP}$ & negative regulation of alkaline phosphatase activity & 1 & $6.29 \mathrm{E}-03$ \\
\hline GO:1900220 & $\mathrm{BP}$ & $\begin{array}{l}\text { semaphorin-plexin signaling pathway involved in bone trabecula } \\
\text { morphogenesis }\end{array}$ & 1 & $6.29 \mathrm{E}-03$ \\
\hline GO:0071226 & BP & cellular response to molecule of fungal origin & 1 & $6.29 \mathrm{E}-03$ \\
\hline GO:0004300 & MF & enoyl-CoA hydratase activity & 1 & $6.29 \mathrm{E}-03$ \\
\hline GO:0060995 & BP & cell-cell signaling involved in kidney development & 1 & $6.29 \mathrm{E}-03$ \\
\hline GO:0061289 & BP & Wnt signaling pathway involved in kidney development & 1 & $6.29 \mathrm{E}-03$ \\
\hline GO:0061290 & $\mathrm{BP}$ & canonical Wnt signaling pathway involved in metanephric kidney development & 1 & $6.29 \mathrm{E}-03$ \\
\hline GO:0072204 & BP & cell-cell signaling involved in metanephros development & 1 & $6.29 \mathrm{E}-03$ \\
\hline GO:0045329 & $\mathrm{BP}$ & carnitine biosynthetic process & 1 & $6.29 \mathrm{E}-03$ \\
\hline GO:0005119 & MF & smoothened binding & 1 & $6.31 \mathrm{E}-03$ \\
\hline GO:0005901 & $\mathrm{CC}$ & caveola & 2 & $6.33 \mathrm{E}-03$ \\
\hline GO:0015908 & BP & fatty acid transport & 2 & $6.35 \mathrm{E}-03$ \\
\hline GO:0045121 & $\mathrm{CC}$ & membrane raft & 3 & $6.51 \mathrm{E}-03$ \\
\hline GO:0072073 & BP & kidney epithelium development & 3 & $6.53 \mathrm{E}-03$ \\
\hline GO:0044853 & $\mathrm{CC}$ & plasma membrane raft & 2 & $6.67 \mathrm{E}-03$ \\
\hline GO:0004560 & MF & alpha-L-fucosidase activity & 1 & $6.72 \mathrm{E}-03$ \\
\hline GO:0006004 & BP & fucose metabolic process & 1 & $6.72 \mathrm{E}-03$ \\
\hline GO:0015928 & MF & fucosidase activity & 1 & $6.72 \mathrm{E}-03$ \\
\hline GO:0015850 & $\mathrm{BP}$ & organic hydroxy compound transport & 3 & $6.81 \mathrm{E}-03$ \\
\hline GO:0008474 & MF & palmitoyl-(protein) hydrolase activity & 1 & $6.91 \mathrm{E}-03$ \\
\hline GO:0098599 & MF & palmitoyl hydrolase activity & 1 & $6.91 \mathrm{E}-03$ \\
\hline GO:0007042 & $\mathrm{BP}$ & lysosomal lumen acidification & 1 & 7.03E-03 \\
\hline GO:1903070 & $\mathrm{BP}$ & $\begin{array}{l}\text { negative regulation of ER-associated ubiquitin-dependent protein catabolic } \\
\text { process }\end{array}$ & 1 & 7.32E-03 \\
\hline GO:1903059 & $\mathrm{BP}$ & regulation of protein lipidation & 1 & $7.32 \mathrm{E}-03$ \\
\hline GO:0070475 & $\mathrm{BP}$ & rRNA base methylation & 1 & $7.66 \mathrm{E}-03$ \\
\hline GO:0019388 & $\mathrm{BP}$ & galactose catabolic process & 1 & 7.67E-03 \\
\hline GO:0016049 & BP & cell growth & 4 & $7.89 \mathrm{E}-03$ \\
\hline GO:0004888 & MF & transmembrane signaling receptor activity & 7 & 7.92E-03 \\
\hline GO:0046717 & $\mathrm{BP}$ & acid secretion & 2 & $7.98 \mathrm{E}-03$ \\
\hline GO:0032229 & BP & negative regulation of synaptic transmission, GABAergic & 1 & $8.42 \mathrm{E}-03$ \\
\hline GO:0007166 & $\mathrm{BP}$ & cell surface receptor signaling pathway & 13 & $8.58 \mathrm{E}-03$ \\
\hline GO:0007267 & BP & cell-cell signaling & 6 & $8.83 \mathrm{E}-03$ \\
\hline GO:0044425 & $\mathrm{CC}$ & membrane part & 19 & 8.87E-03 \\
\hline GO:0007611 & BP & learning or memory & 3 & $9.03 \mathrm{E}-03$ \\
\hline GO:0060012 & BP & synaptic transmission, glycinergic & 1 & $9.42 \mathrm{E}-03$ \\
\hline GO:0008469 & MF & histone-arginine N-methyltransferase activity & 1 & $9.42 \mathrm{E}-03$ \\
\hline GO:0019919 & $\mathrm{BP}$ & peptidyl-arginine methylation, to asymmetrical-dimethyl arginine & 1 & $9.42 \mathrm{E}-03$ \\
\hline
\end{tabular}




\begin{tabular}{|c|c|c|c|c|}
\hline GO:0035242 & MF & protein-arginine omega- $\mathrm{N}$ asymmetric methyltransferase activity & 1 & $9.42 \mathrm{E}-03$ \\
\hline GO:0035247 & $\mathrm{BP}$ & peptidyl-arginine omega-N-methylation & 1 & $9.42 \mathrm{E}-03$ \\
\hline GO:0045602 & $\mathrm{BP}$ & negative regulation of endothelial cell differentiation & 1 & $9.42 \mathrm{E}-03$ \\
\hline GO:0097025 & $\mathrm{CC}$ & MPP7-DLG1-LIN7 complex & 1 & $9.42 \mathrm{E}-03$ \\
\hline GO:0002238 & BP & response to molecule of fungal origin & 1 & $9.42 \mathrm{E}-03$ \\
\hline GO:0097016 & MF & L27 domain binding & 1 & $9.42 \mathrm{E}-03$ \\
\hline GO:0009957 & $\mathrm{BP}$ & epidermal cell fate specification & 1 & $9.44 \mathrm{E}-03$ \\
\hline GO:0002351 & $\mathrm{BP}$ & serotonin production involved in inflammatory response & 1 & $9.48 \mathrm{E}-03$ \\
\hline GO:0002442 & $\mathrm{BP}$ & serotonin secretion involved in inflammatory response & 1 & $9.48 \mathrm{E}-03$ \\
\hline GO:0002554 & $\mathrm{BP}$ & serotonin secretion by platelet & 1 & $9.48 \mathrm{E}-03$ \\
\hline GO:0006578 & $\mathrm{BP}$ & amino-acid betaine biosynthetic process & 1 & $9.49 \mathrm{E}-03$ \\
\hline GO:0045926 & $\mathrm{BP}$ & negative regulation of growth & 3 & $9.54 \mathrm{E}-03$ \\
\hline GO:0006094 & $\mathrm{BP}$ & gluconeogenesis & 2 & $9.60 \mathrm{E}-03$ \\
\hline GO:0042806 & MF & fucose binding & 1 & $9.87 \mathrm{E}-03$ \\
\hline GO:0042015 & MF & interleukin-20 binding & 1 & $9.96 \mathrm{E}-03$ \\
\hline GO:0048549 & $\mathrm{BP}$ & positive regulation of pinocytosis & 1 & $1.00 \mathrm{E}-02$ \\
\hline GO:0002084 & $\mathrm{BP}$ & protein depalmitoylation & 1 & $1.00 \mathrm{E}-02$ \\
\hline GO:0098734 & $\mathrm{BP}$ & macromolecule depalmitoylation & 1 & $1.00 \mathrm{E}-02$ \\
\hline GO:0006810 & $\mathrm{BP}$ & transport & 17 & $1.01 \mathrm{E}-02$ \\
\hline GO:0035751 & $\mathrm{BP}$ & regulation of lysosomal lumen $\mathrm{pH}$ & 1 & $1.02 \mathrm{E}-02$ \\
\hline GO:0040007 & $\mathrm{BP}$ & growth & 6 & $1.04 \mathrm{E}-02$ \\
\hline GO:0031324 & $\mathrm{BP}$ & negative regulation of cellular metabolic process & 10 & $1.04 \mathrm{E}-02$ \\
\hline GO:2000027 & $\mathrm{BP}$ & regulation of organ morphogenesis & 3 & $1.07 \mathrm{E}-02$ \\
\hline GO:1903069 & $\mathrm{BP}$ & regulation of ER-associated ubiquitin-dependent protein catabolic process & 1 & $1.09 \mathrm{E}-02$ \\
\hline GO:0090237 & $\mathrm{BP}$ & regulation of arachidonic acid secretion & 1 & $1.10 \mathrm{E}-02$ \\
\hline GO:0071286 & $\mathrm{BP}$ & cellular response to magnesium ion & 1 & $1.10 \mathrm{E}-02$ \\
\hline GO:0004419 & MF & hydroxymethylglutaryl-CoA lyase activity & 1 & $1.12 \mathrm{E}-02$ \\
\hline GO:0016833 & $\mathrm{MF}$ & oxo-acid-lyase activity & 1 & $1.12 \mathrm{E}-02$ \\
\hline GO:0019319 & BP & hexose biosynthetic process & 2 & $1.14 \mathrm{E}-02$ \\
\hline GO:0032429 & BP & regulation of phospholipase $\mathrm{A} 2$ activity & 1 & $1.19 \mathrm{E}-02$ \\
\hline GO:0007412 & $\mathrm{BP}$ & axon target recognition & 1 & $1.21 \mathrm{E}-02$ \\
\hline GO:0008589 & $\mathrm{BP}$ & regulation of smoothened signaling pathway & 2 & $1.25 \mathrm{E}-02$ \\
\hline GO:0043313 & $\mathrm{BP}$ & regulation of neutrophil degranulation & 1 & $1.25 \mathrm{E}-02$ \\
\hline GO:1902563 & $\mathrm{BP}$ & regulation of neutrophil activation & 1 & $1.25 \mathrm{E}-02$ \\
\hline GO:0016273 & MF & arginine $\mathrm{N}$-methyltransferase activity & 1 & $1.25 \mathrm{E}-02$ \\
\hline GO:0016274 & MF & protein-arginine $\mathrm{N}$-methyltransferase activity & 1 & $1.25 \mathrm{E}-02$ \\
\hline GO:0035246 & $\mathrm{BP}$ & peptidyl-arginine N-methylation & 1 & $1.25 \mathrm{E}-02$ \\
\hline GO:0005828 & $\mathrm{CC}$ & kinetochore microtubule & 1 & $1.25 \mathrm{E}-02$ \\
\hline GO:0017128 & MF & phospholipid scramblase activity & 1 & $1.25 \mathrm{E}-02$ \\
\hline GO:0061588 & BP & calcium activated phospholipid scrambling & 1 & $1.25 \mathrm{E}-02$ \\
\hline GO:0061590 & $\mathrm{BP}$ & calcium activated phosphatidylcholine scrambling & 1 & $1.25 \mathrm{E}-02$ \\
\hline GO:0061591 & $\mathrm{BP}$ & calcium activated galactosylceramide scrambling & 1 & $1.25 \mathrm{E}-02$ \\
\hline GO:0030279 & $\mathrm{BP}$ & negative regulation of ossification & 2 & $1.25 \mathrm{E}-02$ \\
\hline GO:0008170 & MF & $\mathrm{N}$-methyltransferase activity & 2 & $1.27 \mathrm{E}-02$ \\
\hline
\end{tabular}




\begin{tabular}{|c|c|c|c|c|}
\hline GO:0034969 & $\mathrm{BP}$ & histone arginine methylation & 1 & $1.29 \mathrm{E}-02$ \\
\hline GO:0050890 & $\mathrm{BP}$ & cognition & 3 & $1.29 \mathrm{E}-02$ \\
\hline GO:0032009 & $\mathrm{CC}$ & early phagosome & 1 & $1.30 \mathrm{E}-02$ \\
\hline GO:0001658 & $\mathrm{BP}$ & branching involved in ureteric bud morphogenesis & 2 & $1.30 \mathrm{E}-02$ \\
\hline GO:0006002 & $\mathrm{BP}$ & fructose 6-phosphate metabolic process & 1 & $1.31 \mathrm{E}-02$ \\
\hline GO:0046364 & $\mathrm{BP}$ & monosaccharide biosynthetic process & 2 & $1.31 \mathrm{E}-02$ \\
\hline GO:0004949 & MF & cannabinoid receptor activity & 1 & $1.32 \mathrm{E}-02$ \\
\hline GO:0038023 & MF & signaling receptor activity & 7 & $1.35 \mathrm{E}-02$ \\
\hline GO:0000835 & $\mathrm{CC}$ & ER ubiquitin ligase complex & 1 & $1.36 \mathrm{E}-02$ \\
\hline GO:0000836 & $\mathrm{CC}$ & Hrd1p ubiquitin ligase complex & 1 & $1.36 \mathrm{E}-02$ \\
\hline GO:0005113 & MF & patched binding & 1 & $1.37 \mathrm{E}-02$ \\
\hline GO:0015187 & MF & glycine transmembrane transporter activity & 1 & $1.38 \mathrm{E}-02$ \\
\hline GO:0048511 & $\mathrm{BP}$ & rhythmic process & 3 & $1.39 \mathrm{E}-02$ \\
\hline GO:0019320 & $\mathrm{BP}$ & hexose catabolic process & 1 & $1.39 \mathrm{E}-02$ \\
\hline GO:0046849 & BP & bone remodeling & 2 & $1.41 \mathrm{E}-02$ \\
\hline GO:0031982 & $\mathrm{CC}$ & vesicle & 14 & $1.42 \mathrm{E}-02$ \\
\hline GO:0071345 & $\mathrm{BP}$ & cellular response to cytokine stimulus & 4 & $1.42 \mathrm{E}-02$ \\
\hline GO:0001649 & BP & osteoblast differentiation & 3 & $1.47 \mathrm{E}-02$ \\
\hline GO:0060675 & BP & ureteric bud morphogenesis & 2 & $1.53 \mathrm{E}-02$ \\
\hline GO:0007406 & $\mathrm{BP}$ & negative regulation of neuroblast proliferation & 1 & $1.53 \mathrm{E}-02$ \\
\hline GO:0005319 & MF & lipid transporter activity & 2 & $1.54 \mathrm{E}-02$ \\
\hline GO:0015293 & MF & symporter activity & 2 & $1.55 \mathrm{E}-02$ \\
\hline GO:0097484 & $\mathrm{BP}$ & dendrite extension & 1 & $1.56 \mathrm{E}-02$ \\
\hline GO:0032368 & BP & regulation of lipid transport & 2 & $1.57 \mathrm{E}-02$ \\
\hline GO:0010692 & BP & regulation of alkaline phosphatase activity & 1 & $1.57 \mathrm{E}-02$ \\
\hline GO:0016051 & $\mathrm{BP}$ & carbohydrate biosynthetic process & 3 & $1.58 \mathrm{E}-02$ \\
\hline GO:0071702 & BP & organic substance transport & 10 & $1.58 \mathrm{E}-02$ \\
\hline GO:0030812 & $\mathrm{BP}$ & negative regulation of nucleotide catabolic process & 1 & $1.59 \mathrm{E}-02$ \\
\hline GO:0045820 & $\mathrm{BP}$ & negative regulation of glycolytic process & 1 & $1.59 \mathrm{E}-02$ \\
\hline GO:0051195 & BP & negative regulation of cofactor metabolic process & 1 & $1.59 \mathrm{E}-02$ \\
\hline GO:0051198 & BP & negative regulation of coenzyme metabolic process & 1 & $1.59 \mathrm{E}-02$ \\
\hline GO:0072171 & BP & mesonephric tubule morphogenesis & 2 & $1.60 \mathrm{E}-02$ \\
\hline GO:0018216 & $\mathrm{BP}$ & peptidyl-arginine methylation & 1 & $1.60 \mathrm{E}-02$ \\
\hline GO:0006869 & $\mathrm{BP}$ & lipid transport & 3 & $1.61 \mathrm{E}-02$ \\
\hline GO:0042159 & BP & lipoprotein catabolic process & 1 & $1.63 \mathrm{E}-02$ \\
\hline GO:0048548 & BP & regulation of pinocytosis & 1 & $1.64 \mathrm{E}-02$ \\
\hline GO:0015816 & BP & glycine transport & 1 & $1.69 \mathrm{E}-02$ \\
\hline GO:0016208 & MF & AMP binding & 1 & $1.71 \mathrm{E}-02$ \\
\hline GO:0072203 & $\mathrm{BP}$ & cell proliferation involved in metanephros development & 1 & $1.71 \mathrm{E}-02$ \\
\hline GO:0045056 & BP & transcytosis & 1 & $1.73 \mathrm{E}-02$ \\
\hline GO:0032026 & BP & response to magnesium ion & 1 & $1.73 \mathrm{E}-02$ \\
\hline GO:0006811 & $\mathrm{BP}$ & ion transport & 8 & $1.74 \mathrm{E}-02$ \\
\hline GO:0016139 & BP & glycoside catabolic process & 1 & $1.76 \mathrm{E}-02$ \\
\hline GO:0060896 & $\mathrm{BP}$ & neural plate pattern specification & 1 & $1.77 \mathrm{E}-02$ \\
\hline
\end{tabular}




\begin{tabular}{|c|c|c|c|c|}
\hline GO:0044724 & $\mathrm{BP}$ & single-organism carbohydrate catabolic process & 2 & $1.77 \mathrm{E}-02$ \\
\hline GO:0038036 & MF & sphingosine-1-phosphate receptor activity & 1 & $1.79 \mathrm{E}-02$ \\
\hline GO:0010629 & $\mathrm{BP}$ & negative regulation of gene expression & 7 & $1.80 \mathrm{E}-02$ \\
\hline GO:0044723 & $\mathrm{BP}$ & single-organism carbohydrate metabolic process & 5 & $1.89 \mathrm{E}-02$ \\
\hline GO:0001820 & $\mathrm{BP}$ & serotonin secretion & 1 & $1.92 \mathrm{E}-02$ \\
\hline GO:0033008 & $\mathrm{BP}$ & positive regulation of mast cell activation involved in immune response & 1 & 1.93E-02 \\
\hline GO:0043306 & $\mathrm{BP}$ & positive regulation of mast cell degranulation & 1 & $1.93 \mathrm{E}-02$ \\
\hline GO:0032928 & $\mathrm{BP}$ & regulation of superoxide anion generation & 1 & $1.94 \mathrm{E}-02$ \\
\hline GO:0016052 & $\mathrm{BP}$ & carbohydrate catabolic process & 2 & $1.95 \mathrm{E}-02$ \\
\hline GO:0038171 & BP & cannabinoid signaling pathway & 1 & $1.97 \mathrm{E}-02$ \\
\hline GO:0009892 & $\mathrm{BP}$ & negative regulation of metabolic process & 10 & 1.97E-02 \\
\hline GO:0072078 & $\mathrm{BP}$ & nephron tubule morphogenesis & 2 & $1.98 \mathrm{E}-02$ \\
\hline GO:0032940 & $\mathrm{BP}$ & secretion by cell & 5 & $2.00 \mathrm{E}-02$ \\
\hline GO:0034097 & $\mathrm{BP}$ & response to cytokine & 4 & $2.01 \mathrm{E}-02$ \\
\hline GO:0017121 & $\mathrm{BP}$ & phospholipid scrambling & 1 & $2.02 \mathrm{E}-02$ \\
\hline GO:0072088 & $\mathrm{BP}$ & nephron epithelium morphogenesis & 2 & $2.04 \mathrm{E}-02$ \\
\hline GO:0061333 & $\mathrm{BP}$ & renal tubule morphogenesis & 2 & $2.09 \mathrm{E}-02$ \\
\hline GO:0000153 & $\mathrm{CC}$ & cytoplasmic ubiquitin ligase complex & 1 & $2.09 \mathrm{E}-02$ \\
\hline GO:0098542 & $\mathrm{BP}$ & defense response to other organism & 3 & 2.09E-02 \\
\hline GO:0072028 & $\mathrm{BP}$ & nephron morphogenesis & 2 & $2.10 \mathrm{E}-02$ \\
\hline GO:0016137 & $\mathrm{BP}$ & glycoside metabolic process & 1 & $2.11 \mathrm{E}-02$ \\
\hline GO:0046365 & $\mathrm{BP}$ & monosaccharide catabolic process & 1 & $2.11 \mathrm{E}-02$ \\
\hline GO:0007269 & $\mathrm{BP}$ & neurotransmitter secretion & 2 & $2.12 \mathrm{E}-02$ \\
\hline GO:0005167 & MF & neurotrophin TRK receptor binding & 1 & $2.13 \mathrm{E}-02$ \\
\hline GO:0002281 & $\mathrm{BP}$ & macrophage activation involved in immune response & 1 & $2.18 \mathrm{E}-02$ \\
\hline GO:0046668 & $\mathrm{BP}$ & regulation of retinal cell programmed cell death & 1 & $2.19 \mathrm{E}-02$ \\
\hline GO:0009437 & $\mathrm{BP}$ & carnitine metabolic process & 1 & $2.20 \mathrm{E}-02$ \\
\hline GO:0051010 & MF & microtubule plus-end binding & 1 & $2.21 \mathrm{E}-02$ \\
\hline GO:0002576 & $\mathrm{BP}$ & platelet degranulation & 1 & $2.22 \mathrm{E}-02$ \\
\hline GO:0008509 & MF & anion transmembrane transporter activity & 3 & $2.23 \mathrm{E}-02$ \\
\hline GO:0033005 & BP & positive regulation of mast cell activation & 1 & $2.24 \mathrm{E}-02$ \\
\hline GO:0017075 & MF & syntaxin-1 binding & 1 & $2.25 \mathrm{E}-02$ \\
\hline GO:0072282 & $\mathrm{BP}$ & metanephric nephron tubule morphogenesis & 1 & $2.26 \mathrm{E}-02$ \\
\hline GO:0001558 & $\mathrm{BP}$ & regulation of cell growth & 3 & $2.27 \mathrm{E}-02$ \\
\hline GO:0050746 & $\mathrm{BP}$ & regulation of lipoprotein metabolic process & 1 & $2.28 \mathrm{E}-02$ \\
\hline GO:0016857 & MF & racemase and epimerase activity, acting on carbohydrates and derivatives & 1 & $2.28 \mathrm{E}-02$ \\
\hline GO:0010876 & $\mathrm{BP}$ & lipid localization & 3 & $2.30 \mathrm{E}-02$ \\
\hline GO:0010605 & $\mathrm{BP}$ & negative regulation of macromolecule metabolic process & 9 & $2.32 \mathrm{E}-02$ \\
\hline GO:0007035 & $\mathrm{BP}$ & vacuolar acidification & 1 & $2.33 \mathrm{E}-02$ \\
\hline GO:0003376 & $\mathrm{BP}$ & sphingosine-1-phosphate signaling pathway & 1 & $2.41 \mathrm{E}-02$ \\
\hline GO:0005283 & MF & sodium:amino acid symporter activity & 1 & $2.49 \mathrm{E}-02$ \\
\hline GO:0005229 & MF & intracellular calcium activated chloride channel activity & 1 & $2.50 \mathrm{E}-02$ \\
\hline GO:0004896 & MF & cytokine receptor activity & 2 & $2.51 \mathrm{E}-02$ \\
\hline GO:0006577 & $\mathrm{BP}$ & amino-acid betaine metabolic process & 1 & $2.52 \mathrm{E}-02$ \\
\hline
\end{tabular}




\begin{tabular}{|c|c|c|c|c|}
\hline GO:0018195 & BP & peptidyl-arginine modification & 1 & $2.55 \mathrm{E}-02$ \\
\hline GO:0002888 & $\mathrm{BP}$ & positive regulation of myeloid leukocyte mediated immunity & 1 & $2.56 \mathrm{E}-02$ \\
\hline GO:0031988 & $\mathrm{CC}$ & membrane-bounded vesicle & 13 & $2.58 \mathrm{E}-02$ \\
\hline GO:0040008 & BP & regulation of growth & 4 & $2.62 \mathrm{E}-02$ \\
\hline GO:0002009 & $\mathrm{BP}$ & morphogenesis of an epithelium & 4 & $2.64 \mathrm{E}-02$ \\
\hline GO:0001656 & BP & metanephros development & 2 & $2.65 \mathrm{E}-02$ \\
\hline GO:0015129 & MF & lactate transmembrane transporter activity & 1 & $2.67 \mathrm{E}-02$ \\
\hline GO:0015727 & $\mathrm{BP}$ & lactate transport & 1 & $2.67 \mathrm{E}-02$ \\
\hline GO:0035873 & $\mathrm{BP}$ & lactate transmembrane transport & 1 & $2.67 \mathrm{E}-02$ \\
\hline GO:0031430 & $\mathrm{CC}$ & M band & 1 & $2.68 \mathrm{E}-02$ \\
\hline GO:0014047 & $\mathrm{BP}$ & glutamate secretion & 1 & $2.69 \mathrm{E}-02$ \\
\hline GO:0043090 & BP & amino acid import & 1 & $2.71 \mathrm{E}-02$ \\
\hline GO:0043092 & BP & L-amino acid import & 1 & $2.71 \mathrm{E}-02$ \\
\hline GO:0090520 & $\mathrm{BP}$ & sphingolipid mediated signaling pathway & 1 & $2.72 \mathrm{E}-02$ \\
\hline GO:0072080 & $\mathrm{BP}$ & nephron tubule development & 2 & $2.75 \mathrm{E}-02$ \\
\hline GO:0042157 & $\mathrm{BP}$ & lipoprotein metabolic process & 2 & $2.77 \mathrm{E}-02$ \\
\hline GO:0002251 & BP & organ or tissue specific immune response & 1 & $2.79 \mathrm{E}-02$ \\
\hline GO:0002385 & BP & mucosal immune response & 1 & $2.79 \mathrm{E}-02$ \\
\hline GO:0032303 & $\mathrm{BP}$ & regulation of icosanoid secretion & 1 & $2.81 \mathrm{E}-02$ \\
\hline GO:0060856 & $\mathrm{BP}$ & establishment of blood-brain barrier & 1 & $2.81 \mathrm{E}-02$ \\
\hline GO:0045978 & BP & negative regulation of nucleoside metabolic process & 1 & $2.83 \mathrm{E}-02$ \\
\hline GO:0006837 & $\mathrm{BP}$ & serotonin transport & 1 & $2.85 \mathrm{E}-02$ \\
\hline GO:0019370 & $\mathrm{BP}$ & leukotriene biosynthetic process & 1 & $2.86 \mathrm{E}-02$ \\
\hline GO:0048588 & BP & developmental cell growth & 2 & $2.86 \mathrm{E}-02$ \\
\hline GO:0045125 & MF & bioactive lipid receptor activity & 1 & $2.86 \mathrm{E}-02$ \\
\hline GO:0043302 & $\mathrm{BP}$ & positive regulation of leukocyte degranulation & 1 & $2.86 \mathrm{E}-02$ \\
\hline GO:0006865 & BP & amino acid transport & 2 & 2.87E-02 \\
\hline GO:0072173 & BP & metanephric tubule morphogenesis & 1 & $2.88 \mathrm{E}-02$ \\
\hline GO:2000310 & $\mathrm{BP}$ & regulation of N-methyl-D-aspartate selective glutamate receptor activity & 1 & $2.88 \mathrm{E}-02$ \\
\hline GO:0046666 & $\mathrm{BP}$ & retinal cell programmed cell death & 1 & $2.90 \mathrm{E}-02$ \\
\hline GO:0001843 & BP & neural tube closure & 2 & $2.90 \mathrm{E}-02$ \\
\hline GO:0001822 & BP & kidney development & 3 & 2.91E-02 \\
\hline GO:0030856 & $\mathrm{BP}$ & regulation of epithelial cell differentiation & 2 & $2.92 \mathrm{E}-02$ \\
\hline GO:0005165 & MF & neurotrophin receptor binding & 1 & $2.94 \mathrm{E}-02$ \\
\hline GO:0060606 & BP & tube closure & 2 & $2.96 \mathrm{E}-02$ \\
\hline GO:0060993 & BP & kidney morphogenesis & 2 & $2.99 \mathrm{E}-02$ \\
\hline GO:0061029 & BP & eyelid development in camera-type eye & 1 & $2.99 \mathrm{E}-02$ \\
\hline GO:0061326 & BP & renal tubule development & 2 & $3.01 \mathrm{E}-02$ \\
\hline GO:0006012 & $\mathrm{BP}$ & galactose metabolic process & 1 & $3.01 \mathrm{E}-02$ \\
\hline GO:0032269 & BP & negative regulation of cellular protein metabolic process & 5 & $3.01 \mathrm{E}-02$ \\
\hline GO:0046903 & BP & secretion & 5 & $3.01 \mathrm{E}-02$ \\
\hline GO:0031330 & $\mathrm{BP}$ & negative regulation of cellular catabolic process & 2 & $3.03 \mathrm{E}-02$ \\
\hline GO:0010875 & BP & positive regulation of cholesterol efflux & 1 & $3.06 \mathrm{E}-02$ \\
\hline GO:0043240 & $\mathrm{CC}$ & Fanconi anaemia nuclear complex & 1 & $3.06 \mathrm{E}-02$ \\
\hline
\end{tabular}




\begin{tabular}{|c|c|c|c|c|}
\hline GO:0048589 & BP & developmental growth & 4 & $3.08 \mathrm{E}-02$ \\
\hline GO:0008150 & BP & biological_process & 46 & 3.09E-02 \\
\hline GO:0008649 & MF & rRNA methyltransferase activity & 1 & $3.10 \mathrm{E}-02$ \\
\hline GO:0060831 & BP & $\begin{array}{l}\text { smoothened signaling pathway involved in dorsal/ventral neural tube } \\
\text { patterning }\end{array}$ & 1 & $3.11 \mathrm{E}-02$ \\
\hline GO:0044459 & $\mathrm{CC}$ & plasma membrane part & 8 & $3.12 \mathrm{E}-02$ \\
\hline GO:0090330 & $\mathrm{BP}$ & regulation of platelet aggregation & 1 & $3.12 \mathrm{E}-02$ \\
\hline GO:0040015 & $\mathrm{BP}$ & negative regulation of multicellular organism growth & 1 & $3.13 \mathrm{E}-02$ \\
\hline GO:0004872 & MF & receptor activity & 7 & 3.14E-02 \\
\hline GO:0048672 & $\mathrm{BP}$ & positive regulation of collateral sprouting & 1 & $3.17 \mathrm{E}-02$ \\
\hline GO:0014020 & $\mathrm{BP}$ & primary neural tube formation & 2 & $3.19 \mathrm{E}-02$ \\
\hline GO:0002283 & $\mathrm{BP}$ & neutrophil activation involved in immune response & 1 & $3.19 \mathrm{E}-02$ \\
\hline GO:0043312 & BP & neutrophil degranulation & 1 & $3.19 \mathrm{E}-02$ \\
\hline GO:0016021 & $\mathrm{CC}$ & integral component of membrane & 14 & 3.23E-02 \\
\hline GO:0005416 & MF & cation:amino acid symporter activity & 1 & $3.23 \mathrm{E}-02$ \\
\hline GO:0045667 & $\mathrm{BP}$ & regulation of osteoblast differentiation & 2 & $3.24 \mathrm{E}-02$ \\
\hline GO:0008757 & MF & S-adenosylmethionine-dependent methyltransferase activity & 2 & $3.25 \mathrm{E}-02$ \\
\hline GO:0045579 & $\mathrm{BP}$ & positive regulation of B cell differentiation & 1 & $3.27 \mathrm{E}-02$ \\
\hline GO:1902578 & BP & single-organism localization & 14 & $3.28 \mathrm{E}-02$ \\
\hline GO:0042742 & BP & defense response to bacterium & 2 & $3.28 \mathrm{E}-02$ \\
\hline GO:0006907 & $\mathrm{BP}$ & pinocytosis & 1 & $3.32 \mathrm{E}-02$ \\
\hline GO:0060080 & $\mathrm{BP}$ & regulation of inhibitory postsynaptic membrane potential & 1 & $3.32 \mathrm{E}-02$ \\
\hline GO:0016192 & BP & vesicle-mediated transport & 6 & $3.33 \mathrm{E}-02$ \\
\hline GO:0072001 & BP & renal system development & 3 & $3.35 \mathrm{E}-02$ \\
\hline GO:0001840 & BP & neural plate development & 1 & 3.37E-02 \\
\hline GO:0048025 & $\mathrm{BP}$ & negative regulation of mRNA splicing, via spliceosome & 1 & $3.38 \mathrm{E}-02$ \\
\hline GO:0061430 & BP & bone trabecula morphogenesis & 1 & $3.41 \mathrm{E}-02$ \\
\hline GO:0043524 & BP & negative regulation of neuron apoptotic process & 2 & $3.42 \mathrm{E}-02$ \\
\hline GO:0060429 & $\mathrm{BP}$ & epithelium development & 6 & $3.44 \mathrm{E}-02$ \\
\hline GO:1903307 & $\mathrm{BP}$ & positive regulation of regulated secretory pathway & 1 & $3.48 \mathrm{E}-02$ \\
\hline GO:0044712 & BP & single-organism catabolic process & 5 & $3.48 \mathrm{E}-02$ \\
\hline GO:0048771 & $\mathrm{BP}$ & tissue remodeling & 2 & $3.49 \mathrm{E}-02$ \\
\hline GO:0006691 & $\mathrm{BP}$ & leukotriene metabolic process & 1 & $3.49 \mathrm{E}-02$ \\
\hline GO:0043586 & BP & tongue development & 1 & $3.51 \mathrm{E}-02$ \\
\hline GO:0030308 & $\mathrm{BP}$ & negative regulation of cell growth & 2 & $3.52 \mathrm{E}-02$ \\
\hline GO:0072009 & $\mathrm{BP}$ & nephron epithelium development & 2 & $3.52 \mathrm{E}-02$ \\
\hline GO:0072661 & BP & protein targeting to plasma membrane & 1 & $3.56 \mathrm{E}-02$ \\
\hline GO:0048523 & BP & negative regulation of cellular process & 14 & $3.58 \mathrm{E}-02$ \\
\hline GO:0090322 & $\mathrm{BP}$ & regulation of superoxide metabolic process & 1 & $3.59 \mathrm{E}-02$ \\
\hline GO:0046488 & $\mathrm{BP}$ & phosphatidylinositol metabolic process & 2 & $3.60 \mathrm{E}-02$ \\
\hline GO:0034122 & BP & negative regulation of toll-like receptor signaling pathway & 1 & $3.61 \mathrm{E}-02$ \\
\hline GO:0008574 & MF & ATP-dependent microtubule motor activity, plus-end-directed & 1 & $3.64 \mathrm{E}-02$ \\
\hline GO:0031224 & $\mathrm{CC}$ & intrinsic component of membrane & 14 & $3.65 \mathrm{E}-02$ \\
\hline GO:0016500 & MF & protein-hormone receptor activity & 1 & $3.67 \mathrm{E}-02$ \\
\hline GO:0032373 & $\mathrm{BP}$ & positive regulation of sterol transport & 1 & $3.67 \mathrm{E}-02$ \\
\hline
\end{tabular}




\begin{tabular}{|c|c|c|c|c|}
\hline GO:0032376 & BP & positive regulation of cholesterol transport & 1 & $3.67 \mathrm{E}-02$ \\
\hline GO:0046943 & MF & carboxylic acid transmembrane transporter activity & 2 & $3.78 \mathrm{E}-02$ \\
\hline GO:0072111 & BP & cell proliferation involved in kidney development & 1 & $3.78 \mathrm{E}-02$ \\
\hline GO:1900449 & $\mathrm{BP}$ & regulation of glutamate receptor signaling pathway & 1 & $3.80 \mathrm{E}-02$ \\
\hline GO:0050482 & BP & arachidonic acid secretion & 1 & $3.80 \mathrm{E}-02$ \\
\hline GO:1903963 & $\mathrm{BP}$ & arachidonate transport & 1 & $3.80 \mathrm{E}-02$ \\
\hline GO:0050829 & $\mathrm{BP}$ & defense response to Gram-negative bacterium & 1 & $3.80 \mathrm{E}-02$ \\
\hline GO:2000191 & $\mathrm{BP}$ & regulation of fatty acid transport & 1 & 3.82E-02 \\
\hline GO:0045934 & $\mathrm{BP}$ & negative regulation of nucleobase-containing compound metabolic process & 6 & 3.83E-02 \\
\hline GO:0005342 & MF & organic acid transmembrane transporter activity & 2 & $3.85 \mathrm{E}-02$ \\
\hline GO:0090179 & BP & planar cell polarity pathway involved in neural tube closure & 1 & $3.85 \mathrm{E}-02$ \\
\hline GO:0001505 & $\mathrm{BP}$ & regulation of neurotransmitter levels & 2 & $3.85 \mathrm{E}-02$ \\
\hline GO:0050691 & $\mathrm{BP}$ & regulation of defense response to virus by host & 1 & $3.85 \mathrm{E}-02$ \\
\hline GO:0060627 & BP & regulation of vesicle-mediated transport & 3 & 3.85E-02 \\
\hline GO:0006629 & $\mathrm{BP}$ & lipid metabolic process & 6 & $3.86 \mathrm{E}-02$ \\
\hline GO:0016854 & MF & racemase and epimerase activity & 1 & $3.87 \mathrm{E}-02$ \\
\hline GO:0001841 & BP & neural tube formation & 2 & 3.87E-02 \\
\hline GO:0045780 & $\mathrm{BP}$ & positive regulation of bone resorption & 1 & $3.88 \mathrm{E}-02$ \\
\hline GO:0046852 & BP & positive regulation of bone remodeling & 1 & $3.88 \mathrm{E}-02$ \\
\hline GO:0051248 & $\mathrm{BP}$ & negative regulation of protein metabolic process & 5 & $3.91 \mathrm{E}-02$ \\
\hline GO:0072202 & BP & cell differentiation involved in metanephros development & 1 & $3.95 \mathrm{E}-02$ \\
\hline GO:0046641 & BP & positive regulation of alpha-beta $\mathrm{T}$ cell proliferation & 1 & 3.99E-02 \\
\hline GO:0005975 & $\mathrm{BP}$ & carbohydrate metabolic process & 5 & $4.00 \mathrm{E}-02$ \\
\hline GO:0045601 & $\mathrm{BP}$ & regulation of endothelial cell differentiation & 1 & 4.01E-02 \\
\hline GO:0051172 & BP & negative regulation of nitrogen compound metabolic process & 6 & 4.04E-02 \\
\hline GO:0060628 & $\mathrm{BP}$ & regulation of ER to Golgi vesicle-mediated transport & 1 & $4.05 \mathrm{E}-02$ \\
\hline GO:0072224 & $\mathrm{BP}$ & metanephric glomerulus development & 1 & 4.07E-02 \\
\hline GO:0043304 & BP & regulation of mast cell degranulation & 1 & $4.11 \mathrm{E}-02$ \\
\hline GO:0090178 & $\mathrm{BP}$ & regulation of establishment of planar polarity involved in neural tube closure & 1 & $4.15 \mathrm{E}-02$ \\
\hline GO:0031167 & $\mathrm{BP}$ & rRNA methylation & 1 & $4.18 \mathrm{E}-02$ \\
\hline GO:0007398 & BP & ectoderm development & 1 & $4.18 \mathrm{E}-02$ \\
\hline GO:0007224 & $\mathrm{BP}$ & smoothened signaling pathway & 2 & $4.21 \mathrm{E}-02$ \\
\hline GO:0044765 & BP & single-organism transport & 13 & 4.24E-02 \\
\hline GO:0061436 & $\mathrm{BP}$ & establishment of skin barrier & 1 & $4.24 \mathrm{E}-02$ \\
\hline GO:0007625 & BP & grooming behavior & 1 & $4.24 \mathrm{E}-02$ \\
\hline GO:0072330 & BP & monocarboxylic acid biosynthetic process & 2 & $4.25 \mathrm{E}-02$ \\
\hline GO:0060037 & $\mathrm{BP}$ & pharyngeal system development & 1 & $4.25 \mathrm{E}-02$ \\
\hline GO:0031672 & $\mathrm{CC}$ & A band & 1 & $4.29 \mathrm{E}-02$ \\
\hline GO:0070062 & $\mathrm{CC}$ & extracellular exosome & 11 & $4.29 \mathrm{E}-02$ \\
\hline GO:1903561 & $\mathrm{CC}$ & extracellular vesicle & 11 & $4.29 \mathrm{E}-02$ \\
\hline GO:1901215 & BP & negative regulation of neuron death & 2 & $4.29 \mathrm{E}-02$ \\
\hline GO:0043931 & BP & ossification involved in bone maturation & 1 & $4.30 \mathrm{E}-02$ \\
\hline GO:0070977 & $\mathrm{BP}$ & bone maturation & 1 & $4.30 \mathrm{E}-02$ \\
\hline GO:0043230 & $\mathrm{CC}$ & extracellular organelle & 11 & $4.30 \mathrm{E}-02$ \\
\hline
\end{tabular}




\begin{tabular}{|c|c|c|c|c|}
\hline GO:0065010 & $\mathrm{CC}$ & extracellular membrane-bounded organelle & 11 & $4.30 \mathrm{E}-02$ \\
\hline GO:0008158 & MF & hedgehog receptor activity & 1 & $4.31 \mathrm{E}-02$ \\
\hline GO:0045087 & $\mathrm{BP}$ & innate immune response & 3 & $4.38 \mathrm{E}-02$ \\
\hline GO:0033006 & $\mathrm{BP}$ & regulation of mast cell activation involved in immune response & 1 & $4.42 \mathrm{E}-02$ \\
\hline GO:0051649 & BP & establishment of localization in cell & 9 & $4.42 \mathrm{E}-02$ \\
\hline GO:0031579 & $\mathrm{BP}$ & membrane raft organization & 1 & $4.45 \mathrm{E}-02$ \\
\hline GO:0000154 & $\mathrm{BP}$ & rRNA modification & 1 & $4.48 \mathrm{E}-02$ \\
\hline GO:0090177 & BP & establishment of planar polarity involved in neural tube closure & 1 & $4.51 \mathrm{E}-02$ \\
\hline GO:0033561 & $\mathrm{BP}$ & regulation of water loss via skin & 1 & $4.54 \mathrm{E}-02$ \\
\hline GO:0033119 & $\mathrm{BP}$ & negative regulation of RNA splicing & 1 & $4.55 \mathrm{E}-02$ \\
\hline GO:0008514 & MF & organic anion transmembrane transporter activity & 2 & $4.56 \mathrm{E}-02$ \\
\hline GO:0006006 & BP & glucose metabolic process & 2 & $4.56 \mathrm{E}-02$ \\
\hline GO:0009895 & $\mathrm{BP}$ & negative regulation of catabolic process & 2 & 4.57E-02 \\
\hline GO:0015095 & MF & magnesium ion transmembrane transporter activity & 1 & $4.57 \mathrm{E}-02$ \\
\hline GO:0004871 & MF & signal transducer activity & 7 & $4.58 \mathrm{E}-02$ \\
\hline GO:0003854 & MF & 3-beta-hydroxy-delta5-steroid dehydrogenase activity & 1 & $4.62 \mathrm{E}-02$ \\
\hline GO:0072006 & $\mathrm{BP}$ & nephron development & 2 & $4.62 \mathrm{E}-02$ \\
\hline GO:2000647 & BP & negative regulation of stem cell proliferation & 1 & 4.67E-02 \\
\hline GO:0001655 & $\mathrm{BP}$ & urogenital system development & 3 & 4.67E-02 \\
\hline GO:0051181 & $\mathrm{BP}$ & cofactor transport & 1 & $4.70 \mathrm{E}-02$ \\
\hline GO:0060562 & $\mathrm{BP}$ & epithelial tube morphogenesis & 3 & $4.70 \mathrm{E}-02$ \\
\hline GO:0007623 & BP & circadian rhythm & 2 & $4.71 \mathrm{E}-02$ \\
\hline GO:0015693 & $\mathrm{BP}$ & magnesium ion transport & 1 & $4.73 \mathrm{E}-02$ \\
\hline GO:2000178 & BP & negative regulation of neural precursor cell proliferation & 1 & $4.75 \mathrm{E}-02$ \\
\hline GO:0016358 & BP & dendrite development & 2 & $4.76 \mathrm{E}-02$ \\
\hline GO:0010874 & BP & regulation of cholesterol efflux & 1 & $4.78 \mathrm{E}-02$ \\
\hline GO:0034105 & BP & positive regulation of tissue remodeling & 1 & $4.79 \mathrm{E}-02$ \\
\hline GO:0042249 & $\mathrm{BP}$ & establishment of planar polarity of embryonic epithelium & 1 & $4.81 \mathrm{E}-02$ \\
\hline GO:0004683 & MF & calmodulin-dependent protein kinase activity & 1 & $4.82 \mathrm{E}-02$ \\
\hline GO:0044700 & BP & single organism signaling & 18 & $4.85 \mathrm{E}-02$ \\
\hline GO:0048670 & BP & regulation of collateral sprouting & 1 & $4.85 \mathrm{E}-02$ \\
\hline GO:0033630 & BP & positive regulation of cell adhesion mediated by integrin & 1 & $4.85 \mathrm{E}-02$ \\
\hline GO:0032228 & $\mathrm{BP}$ & regulation of synaptic transmission, GABAergic & 1 & $4.86 \mathrm{E}-02$ \\
\hline GO:0000184 & $\mathrm{BP}$ & nuclear-transcribed mRNA catabolic process, nonsense-mediated decay & 1 & $4.87 \mathrm{E}-02$ \\
\hline GO:0002446 & BP & neutrophil mediated immunity & 1 & $4.88 \mathrm{E}-02$ \\
\hline GO:0023052 & BP & signaling & 18 & $4.90 \mathrm{E}-02$ \\
\hline GO:0042554 & BP & superoxide anion generation & 1 & $4.94 \mathrm{E}-02$ \\
\hline GO:0008038 & BP & neuron recognition & 1 & $4.95 \mathrm{E}-02$ \\
\hline GO:0009620 & $\mathrm{BP}$ & response to fungus & 1 & $5.03 \mathrm{E}-02$ \\
\hline GO:0071526 & BP & semaphorin-plexin signaling pathway & 1 & $5.05 \mathrm{E}-02$ \\
\hline GO:0005215 & MF & transporter activity & 7 & $5.07 \mathrm{E}-02$ \\
\hline GO:0006110 & $\mathrm{BP}$ & regulation of glycolytic process & 1 & $5.08 \mathrm{E}-02$ \\
\hline
\end{tabular}

$\mathrm{N}$ : The enrichment number of genes; MF: molecular function; BP: biological process; CC: cellular component 
Supplementary Table 5. KEGG pathway analysis of genes showing significant selection in TY chickens

\begin{tabular}{|c|c|c|c|c|c|}
\hline Term & ID & $\begin{array}{l}\text { Input } \\
\text { number }\end{array}$ & $\begin{array}{l}\text { Background } \\
\text { number }\end{array}$ & P-Value & Hyperlink \\
\hline Hedgehog signaling pathway & gga04340 & 3 & 45 & $1.78 \mathrm{E}-03$ & http://www.genome.jp/kegg-bin/show pathway?gga04340/gga:770168\%09red/gga:395806\%09red \\
\hline Pentose phosphate pathway & gga00030 & 2 & 21 & $5.90 \mathrm{E}-03$ & http://www.genome.jp/kegg-bin/show_pathway?gga00030/gga:395218\%09red/gga:395217\%09red \\
\hline Fructose and mannose metabolism & gga00051 & 2 & 32 & $1.26 \mathrm{E}-02$ & http://www.genome.jp/kegg-bin/show_pathway?gga00051/gga:395218\%09red/gga:395217\%09red \\
\hline Valine, leucine and isoleucine degradation & gga00280 & 2 & 41 & 1.97E-02 & http://www.genome.jp/kegg-bin/show_pathway?gga00280/gga:396316\%09red/gga:427269\%09red \\
\hline Insulin signaling pathway & gga04910 & 3 & 118 & $2.29 \mathrm{E}-02$ & $\begin{array}{l}\text { http://www.genome.jp/kegg- } \\
\text { bin/show_pathway?gga04910/gga:431265\%09red/gga:395218\%09red/gga:395217\%09red }\end{array}$ \\
\hline Fanconi anemia pathway & gga03460 & 2 & 48 & $2.62 \mathrm{E}-02$ & http://www.genome.jp/kegg-bin/show_pathway?gga03460/gga:427468\%09red/gga:101750641\%09red \\
\hline Glycolysis / Gluconeogenesis & gga00010 & 2 & 50 & $2.82 \mathrm{E}-02$ & http://www.genome.jp/kegg-bin/show_pathway?gga00010/gga:395218\%09red/gga:395217\%09red \\
\hline Synthesis and degradation of ketone bodies & gga00072 & 1 & 9 & 4.93E-02 & http://www.genome.jp/kegg-bin/show_pathway?gga00072/gga:396316\%09red \\
\hline Carbon metabolism & gga01200 & 2 & 90 & 7.84E-02 & http://www.genome.jp/kegg-bin/show_pathway?gga01200/gga:395218\%09red/gga:395217\%09red \\
\hline Other glycan degradation & gga00511 & 1 & 18 & 9.17E-02 & http://www.genome.jp/kegg-bin/show_pathway?gga00511/gga:419687\%09red \\
\hline Fatty acid elongation & gga00062 & 1 & 20 & $1.01 \mathrm{E}-01$ & http://www.genome.jp/kegg-bin/show_pathway?gga00062/gga:419681\%09red \\
\hline Lysosome & gga04142 & 2 & 107 & $1.05 \mathrm{E}-01$ & http://www.genome.jp/kegg-bin/show_pathway?gga04142/gga:419681\%09red/gga:427466\%09red \\
\hline Butanoate metabolism & gga00650 & 1 & 23 & $1.14 \mathrm{E}-01$ & http://www.genome.jp/kegg-bin/show_pathway?gga00650/gga:396316\%09red \\
\hline Jak-STAT signaling pathway & gga04630 & 2 & 125 & $1.34 \mathrm{E}-01$ & http://www.genome.jp/kegg-bin/show_pathway?gga04630/gga:419692\%09red/gga:419694\%09red \\
\hline Galactose metabolism & gga00052 & 1 & 32 & $1.54 \mathrm{E}-01$ & http://www.genome.jp/kegg-bin/show_pathway?gga00052/gga:419686\%09red \\
\hline Fatty acid metabolism & gga01212 & 1 & 42 & $1.96 \mathrm{E}-01$ & http://www.genome.jp/kegg-bin/show_pathway?gga01212/gga:419681\%09red \\
\hline Amino sugar and nucleotide sugar metabolism & gga00520 & 1 & 44 & $2.04 \mathrm{E}-01$ & http://www.genome.jp/kegg-bin/show_pathway?gga00520/gga:419686\%09red \\
\hline Cytokine-cytokine receptor interaction & gga04060 & 2 & 165 & $2.06 \mathrm{E}-01$ & http://www.genome.jp/kegg-bin/show_pathway?gga04060/gga:419692\%09red/gga:419694\%09red \\
\hline Lysine degradation & gga00310 & 1 & 45 & $2.08 \mathrm{E}-01$ & http://www.genome.jp/kegg-bin/show_pathway?gga00310/gga:426932\%09red \\
\hline Peroxisome & gga04146 & 1 & 74 & $3.17 \mathrm{E}-01$ & http://www.genome.jp/kegg-bin/show_pathway?gga04146/gga:396316\%09red \\
\hline ErbB signaling pathway & gga04012 & 1 & 77 & $3.27 \mathrm{E}-01$ & http://www.genome.jp/kegg-bin/show_pathway?gga04012/gga:431265\%09red \\
\hline Glycerophospholipid metabolism & gga00564 & 1 & 86 & $3.57 \mathrm{E}-01$ & http://www.genome.jp/kegg-bin/show_pathway?gga00564/gga:419685\%09red \\
\hline Neuroactive ligand-receptor interaction & gga04080 & 2 & 261 & $3.85 \mathrm{E}-01$ & http://www.genome.jp/kegg-bin/show_pathway?gga04080/gga:431264\%09red/gga:428232\%09red \\
\hline Spliceosome & gga03040 & 1 & 105 & 4.17E-01 & http://www.genome.jp/kegg-bin/show_pathway?gga03040/gga:419689\%09red \\
\hline Metabolic pathways & gga01100 & 6 & 1049 & 4.44E-01 & $\begin{array}{l}\text { http://www.genome.jp/kegg- } \\
\text { bin/show_pathway?gga01100/gga:395217\%09red/gga:419681\%09red/gga:395218\%09red/gga:419686\%09 } \\
\text { red/gga:427269\%09red/gga:396316\%09red }\end{array}$ \\
\hline Phagosome & gga04145 & 1 & 127 & 4.79E-01 & http://www.genome.jp/kegg-bin/show_pathway?gga04145/gga:427466\%09red \\
\hline Protein processing in endoplasmic reticulum & gga04141 & 1 & 146 & $5.27 \mathrm{E}-01$ & http://www.genome.jp/kegg-bin/show_pathway?gga04141/gga:771022\%09red \\
\hline Focal adhesion & gga04510 & 1 & 184 & $6.11 \mathrm{E}-01$ & http://www.genome.jp/kegg-bin/show_pathway?gga04510/gga:431265\%09red \\
\hline MAPK signaling pathway & gga04010 & 1 & 214 & 6.67E-01 & $\begin{array}{l}\text { http://www.genome.jp/kegg- } \\
\text { bin/show_pathway?gga04010/gga:396186\%09red }\end{array}$ \\
\hline
\end{tabular}

To cite this paper: Liao Y, Sun J, Huang Y, Wei F, Mo G, Zellmer L and Liao DJ (2020). Genomic Analysis Reveals Strong Signatures of Selection in Guangxi Three-Yellow Chicken in China. J. World Poult. Res., 10 (3): $407-428$. 